\title{
Concentration homeostasis and elements in hair and dried serum observed by X-ray fluorescence analysis using synchrotron radiation
}

\author{
Jun-ichi Chikawa ${ }^{\mathrm{a}, *}$, Yoshitaka Mouri ${ }^{\mathrm{b}}$, Hiroki Shima ${ }^{\mathrm{c}}$, Kousaku Yamada ${ }^{\mathrm{a}}$, \\ Hitoshi Yamamoto ${ }^{\mathrm{d}}$ and Shingo Yamamoto ${ }^{\mathrm{e}}$ \\ ${ }^{a}$ Hyogo Science and Technology Association, Himeji, Japan \\ ${ }^{\mathrm{b}}$ Himeji Health Centre, Sakata, Himeji, Japan \\ ${ }^{\mathrm{c}}$ Shima Institute for Quantum Medicine, Kitaku, Osaka, Japan \\ ${ }^{\mathrm{d}}$ Osaka Breast Clinic, Fukushima, Fukushima-ku, Osaka, Japan \\ ${ }^{\mathrm{e}}$ Hyogo College of Medicine, Nishinomiya, Hyogo, Japan
}

Received 10 September 2013

Revised 6 April 2014

Accepted 25 April 2014

\begin{abstract}
Elemental concentrations in hair and dried serum have been evaluated by X-ray fluorescence analysis using relative concentration independent of specimen thickness. Dried serum samples from 5 male and 5 female subjects given two-week Ca supplementation showed the same concentration for $\mathrm{Ca}$, and for each of the other elements $\mathrm{Cl}, \mathrm{K}, \mathrm{S}$ and $\mathrm{P}$ under renal control by parathyroid hormone (PTH). Hair concentrations of these elements have been evaluated for 50 randomly-selected females aged between 30 and 80. It was found that each element has two distinct levels in hair. The content of an element in growing hair must be equal to the inflow of that element into the hair-making cells from serum. Using this principle, the two levels can be attributed to the gating and closing of the ion channels in cell membranes and given as functions of the dried serum standard concentrations. Especially, the difference between $[\mathrm{Ca}]$ and $[\mathrm{Sr}]$ in hair shows whether $\mathrm{Ca}$ channels are gating or closing. The lower level of hair $[\mathrm{Ca}]_{\mathrm{H}}$ is normal and is equal to $1 / 2$ of the dried serum $[\mathrm{Ca}]$; only the $\mathrm{Ca}$ on serum protein is to be incorporated into the hair in steady-state growth. Store-operated $\mathrm{Ca}$ channel gating occurs so as to maintain the normal $[\mathrm{Ca}]_{\mathrm{H}}$. The higher level is seen in cases of calcium deficiency, and implicated in other disease states. Prolonged Ca deficiency causes a higher hair $[\mathrm{Ca}]_{\mathrm{H}}$ with Ca channel closing. PTH-operated Ca channel gating induces the $\mathrm{Ca}^{2+}$ inflow into the cells to form the hair $[\mathrm{Ca}]_{\mathrm{H}}$ upper level and to deteriorate cell functions such as excretion of excess metals by hepatocytes. Hair analysis provides a new diagnostic tool based on cell ion channels.
\end{abstract}

Keywords: Hair and serum elements, Ca deficiency, ion channels, parathyroid hormone PTH

\footnotetext{
${ }^{*}$ Corresponding author: Jun-ichi Chikawa, Hyogo Science and Technology Association, Shimodera-cho 43, Himeji 6708505, Japan. Tel.: +81 79287 1212; Fax: +81 79287 1220; E-mail: chikawa@ hyogosta.jp.
}

0895-3996/14/\$27.50 (C) 2014 - IOS Press and the authors. All rights reserved

This article is published online with Open Access and distributed under the terms of the Creative Commons Attribution NonCommercial License. 


\section{Introduction}

Analysis of small segments of single hair strands is possible by PIXE (Particle Induced X-ray Emission) $[1,2]$ and XFA (X-ray Fluorescence Analysis) $[1,3-5]$ with synchrotron radiation. In order to make the hair analysis useful, the relation between elemental concentration of hair and serum must be clarified. There were two problems: (1) The intensity of fluorescent X-rays from a single hair sample varies depending upon hair thickness and shape, making it difficult to obtain precise concentrations [1,2]. (2) It has been unknown what hair concentrations tell us about element concentrations within the body.

For precise measurement of elemental concentrations, it is necessary to measure accurately the mass of the hair within the excitation beam. Although this is difficult, other investigators have used X-ray techniques to measure the concentration of various elements in hair $[1,2]$. Other techniques can be used for more fully quantitative analysis, or XFA can be correlated to hair analyses with atomic absorption or ICP analysis. However, these approaches can vastly increase the cost and the time required for small-scale studies. Instead of such absolute measurement, the authors employed a method with a logarithmic ratio of peak to background to obtain the relative concentrations that are independent of hair thickness and shapes [6]. In other words, by neglecting the absolute value, we can obtain relative values which appear to be both useful and reliable. By this method, it was shown that hair $\mathrm{Ca}$ concentrations are separated into upper and lower levels, depending upon the level of Ca deficiency; the upper level is 5 times higher than the lower level. This is seen in hair samples of dozens of subjects. The pattern of calcium levels is distinct, and in other work by the authors [6] has been classified into several types. Various elements such as $\mathrm{Cl}$ (and $\mathrm{Br}$ ) under renal control were also found to have two levels in concentration. Although many investigators have done hair analysis, no other work has reported the two concentration levels in hair elements. Perhaps owing to large variations of the values measured as the absolute concentration, or the large amount of hair required by their method, they have used an average of the measured values as the standard, which is meaningless with the existence of the two levels.

The content of an element in growing hair must be equal to its inflow into the hair matrix cells via hair papilla from serum. By this principle of the "inflow-outflow equality", hair analysis gives information on inflow of various elements into cells from serum. The inflow is closely associated to operational statuses of the molecular ion pumps and ion channels of the cells. Especially, the observed upper level and lower level of hair [Ca] can be attributed to gating and closing of $\mathrm{Ca}$ ion channels in the hair-making cells holding the hair root, respectively. The upper level of hair $[\mathrm{Ca}]$ is closely related to disease states and possibly disease origins. For example, concentration variations from hair root to tip for breast-cancer patients suggest that cancer is always generated during the long-lasting upper level of hair [Ca] which decreases toward the lower level with the cancer growth [6].

To establish the hair analysis as a new health diagnosis, the present paper gives the results for hair concentrations of $\mathrm{Cu}, \mathrm{Ti}, \mathrm{Ca}, \mathrm{Sr}, \mathrm{Cl}, \mathrm{Br}, \mathrm{K}, \mathrm{S}$ and $\mathrm{P}$ under hepatic and renal control. $\mathrm{Ca}$ is the central player in the regulation of these elements, and Ca deficiency is classified into four types. Although there are many kinds of ion channels in cells, we use simple models to show the rationale for our diagnosis and to provide quantitative agreement between the calculated and observed concentration changes in hair. Throughout the work, the knowledge in semiconductor crystal growth has been applied for hair growth [6], although the results obtained phenomenologically may be beyond general understanding in biology.

\section{Samples and method}

All the hair and blood samples were collected after the patients' informed consent was obtained at the 
related hospitals and departments in accordance with ethical standards. Some of the samples were used for the previous work [6].

The hair samples were washed with distilled water and were dried. Serum was separated from the blood samples by a centrifugal separator. A small drop of the serum was placed on a 'Mylar' polyester film with a thickness of about $1 \mu \mathrm{m}$ and was well dried in clean air.

$\mathrm{X}$-ray fluorescence analysis (XFA) of the serum and hair samples was carried out in vacuum using synchrotron radiation at the Photon Factory (PF) BL4A bending magnet beamline [3], where the excitation X-ray beam was monochromatized at a photon energy of $17.4 \mathrm{keV}(0.71 \AA$ A $)$ by a silicon crystal and had a beam size of $0.5 \times 1.4 \mathrm{~mm}$ on the sample. The BL-4A workstation has been rated as capable of producing over $10^{7}$ photons per sec. monochromatized radiation. The beam size corresponds to a growth length of hair for 5 days (hair growth rate: $0.3 \mathrm{~mm} /$ day). Many elements have a daily-cycle of concentration, and an average for 5 days is suitable for knowing health state from hair elements.

The fluorescent $\mathrm{X}$-rays were measured with an $\mathrm{Si}(\mathrm{Li})$ detector and multi-channel pulse height analyzer, and a spectrum of hair can be obtained in a few minutes. For $\mathrm{Ca}$, the $\mathrm{CaK} \beta$ peak height was measured because $\mathrm{CaK} \alpha$ is unresolvable from $\mathrm{KK} \beta$. For the other elements, $\mathrm{K} \alpha$ peaks were used for the concentration measurement. It is essential to exclude air to avoid the $2.96 / 3.19 \mathrm{keV}$ fluorescence of atmospheric argon, which interferes with the measurement of $\mathrm{Cl}$ and $\mathrm{K}$ peaks.

\section{Elemental concentrations in hair}

Serum contains many kinds of proteins such as albumin, globulin and fibrinogen. Generally, an element $\mathrm{X}$ in serum exists in two phases: as atoms in or bound to the protein molecules, and as ions in the liquid. The total concentration $[\mathrm{X}]_{\mathrm{S}}$ in dried serum is expressed as,

$$
[\mathrm{X}]_{\mathrm{S}}=[\mathrm{X}]_{\mathrm{I}}+[\mathrm{X}]_{\mathrm{P}}
$$

where $[X]_{I}$ and $[X]_{P}$ are derived from serum $X$ ions and $X$ atoms in serum protein, respectively. By the principle of the inflow-outflow equality, hair $[\mathrm{X}]_{\mathrm{H}}$ concentrations are divided into two levels depending on whether the ion channels of element X are gating or closing in the "hair-making cells" (HM cells) of hair papilla. (Hair matrix cells are dried to become hair.)

The nomenclature for concentration of element $\mathrm{X}$ is listed as follows:

$[\mathrm{X}]_{\mathrm{S}}$ is the concentration in dried serum.

$[\mathrm{X}]_{\mathrm{P}}$ is the protein-bound concentration in dried serum, after subtracting the $\mathrm{X}$ ions.

$[\mathrm{X}]_{\mathrm{I}}$ is the ion concentration given by $[\mathrm{X}]_{\mathrm{I}}=[\mathrm{X}]_{\mathrm{S}}-[\mathrm{X}]_{\mathrm{P}}$.

$[\mathrm{X}]_{\mathrm{H}}$ is the concentration in hair.

$[\mathrm{X}]_{\mathrm{HO}}$ is the hair concentration in the case of the gating (open) ion channels of cells.

$[\mathrm{X}]_{\mathrm{HC}}$ is the hair concentration in the case of the closing ion channels of cells.

Since serum contains water at $91 \%$, protein at $7 \%$, and minerals at $0.9 \%$, dried serum consists mainly of serum protein, i.e., $[\mathrm{X}]_{\mathrm{P}}$ can be considered to correspond to the number of $\mathrm{X}$ atoms per protein molecule in serum.

\subsection{The logarithmic quantification}

To obtain $[\mathrm{X}]$ independently of specimen thickness, we express $[\mathrm{X}]$ on a logarithmic scale. When spectral peak heights, $A$ and $B$, are observed for thin and thick specimens by XFA, respectively, a 


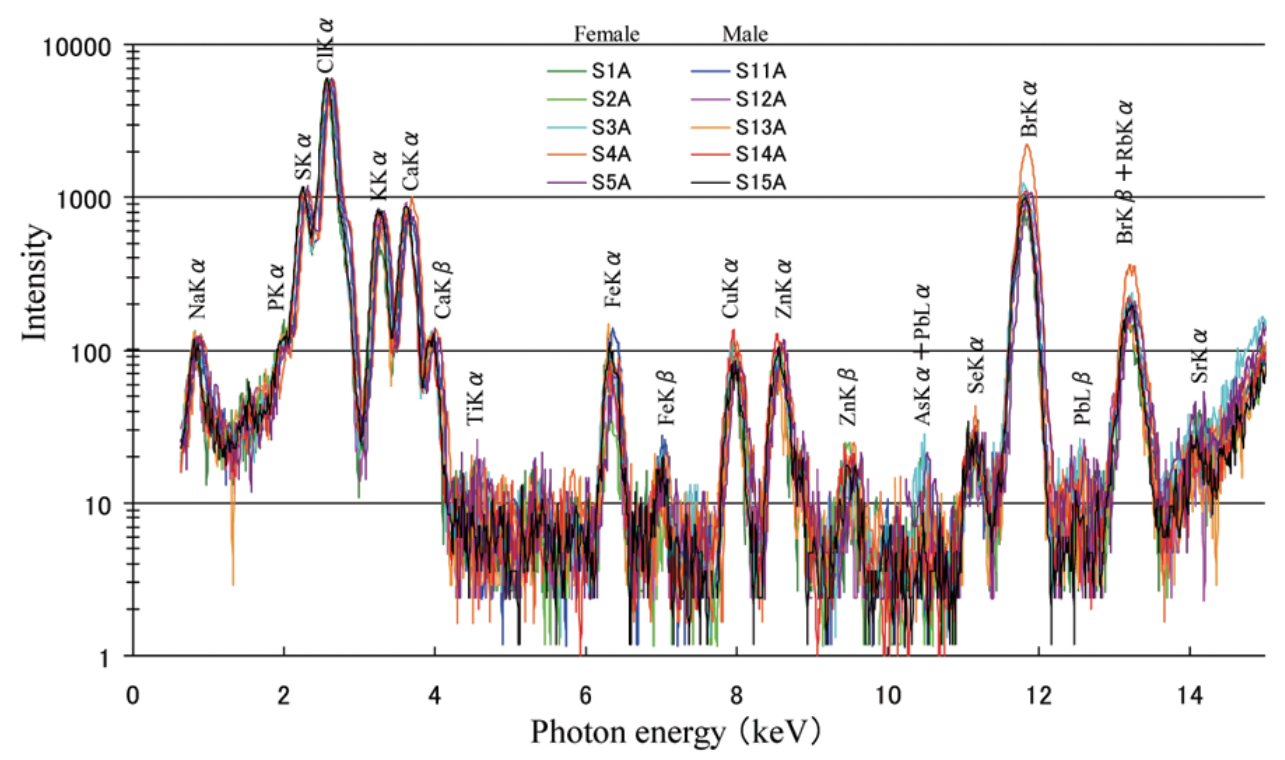

Fig. 1. Elemental concentrations in dried serum samples from 10 subjects (5 for each sex) measured by X-ray fluorescence analysis (XFA) after 2-week supplementation of Ca $900 \mathrm{mg}$ /day. Their spectra are shown superimposed so as to have the same background level. All the concentrations measured by Eq. (2) are listed in Table 1. (Colours are visible in the online version of the article; http://dx.doi.org/10.3233/XST-140439)

relation of $A=\alpha B$ holds, where $\alpha$ is the proportional constant, i.e., $\log A=\log \alpha B=\log B+\log \alpha$. If the concentration is the same, the two peaks, $\log A$ and $\log B$, can be superimposed with moving by $\log \alpha$. Therefore, the concentration [X] of $\mathrm{X}$ in a specimen is given by

$$
\log [\mathrm{X}]=\log P-\log S=\log (P / S),
$$

independently of the specimen thickness, where $P$ is the peak height for element $\mathrm{X}$ and $S$ is the background due to X-rays scattered by the sample. Equation (2) is valid even for thick specimens because the X-ray absorption occurs for $P$ and $S$ in the same way. Since $S$ is also proportional to the mass of the sample within the excitation beam, $P / S$ corresponds to the concentration. (The hair was suspended in the X-ray beam in vacuum, so there is no other mass to account for). In other words, [X] in Eq. (2) is measured by using $S$ as a unit. Therefore, even when two elements, $\mathrm{X}$ and $\mathrm{Z}$, have the relation of $\log [\mathrm{X}]=\log [\mathrm{Z}]([\mathrm{X}]=[\mathrm{Z}])$ by Eq. (2), the $S$ value for the two elements may be different (the spectral peaks of $X$ and $Z$ appear at different wavelengths), and the equality $[X]=[Z]$ means a proportionality between $[\mathrm{X}]$ and $[\mathrm{Z}]$. To determine the proportional constant, another experimental datum is needed. For each peak analyzed, the Gaussian contribution from its neighbouring peaks was subtracted, and the corrected emission was then divided by the background level. (In the conventional method, $P-S$ is divided by the mass obtained by other means.)

The peak height $P$ and background $S$ for the dried serum comes from the $\mathrm{X}$ atoms and protein in the original serum, respectively, and $[\mathrm{X}]=P / S$ gives the mean value for the number of $\mathrm{X}$ atoms per serum protein molecule, since dried serum can be considered as the serum protein containing mineral elements.

To find the standard normal concentrations in serum, 5 male and 5 female subjects were selected in an age range from 19 to 39. Blood samples were taken after oral supplementation of Ca $900 \mathrm{mg} /$ day for two weeks (See Section 3.3) and were made into the dried serum specimens. The FX spectra for the dried 
Table 1

The observed concentrations defined by Eq. (2) in dried serum and hair

\begin{tabular}{cccccccccccc}
\hline & $\mathrm{Cu}$ & $\mathrm{Ti}$ & $\mathrm{Ca}$ & $\mathrm{Sr}$ & $\mathrm{Cl}$ & $\mathrm{Br}$ & $\mathrm{K}$ & $\mathrm{S}$ & $\mathrm{P}$ & $\mathrm{Zn}$ & $\mathrm{Fe}$ \\
\hline$[\mathrm{X}]_{\mathrm{S}}$ S1A & 20 & 2 & 20 & 20 & 250 & 250 & 40 & 40 & 4 & 18 & 17 \\
S2A & 20 & 2 & 20 & 20 & 250 & 250 & 40 & 40 & 4 & 20 & 9 \\
S3A & 20 & 1.5 & 20 & 20 & 250 & 250 & 40 & 40 & 4 & 15 & 15 \\
S4A & 19 & 1 & 20 & 20 & 250 & 250 & 40 & 40 & 4 & 20 & 15 \\
S5A & 17 & 1.5 & 20 & 20 & 250 & 250 & 40 & 40 & 4 & 20 & 15 \\
S11A & 10 & 1 & 20 & 20 & 250 & 250 & 40 & 40 & 4 & 20 & 23 \\
S12A & 18 & 4 & 20 & 20 & 250 & 250 & 40 & 40 & 4 & 20 & 15 \\
S13A & 20 & 3 & 20 & 20 & 250 & 250 & 35 & 40 & 4 & 20 & 30 \\
S14A & 20 & 1.5 & 20 & 20 & 250 & 250 & 40 & 40 & 4 & 20 & 15 \\
S15A & 20 & 1 & 20 & 20 & 250 & 250 & 40 & 40 & 4 & 20 & 18 \\
Standard & 20 & 1 & 20 & 20 & 250 & 250 & 40 & 40 & 4 & 20 & 15 \\
{$[\mathrm{X}]_{\text {HC }}$} & 20 & 1 & 10 & 10 & 10 & 10 & 300 & 20 & $\geqslant 10$ & 400 & 15 \\
{$[\mathrm{X}]_{\text {HO }}$} & & & 50 & 200 & 22 & 22 & & 200 & 5 & & \\
\hline $\mathrm{X}$ & & & & & & & & &
\end{tabular}

$[\mathrm{X}]_{\mathrm{S}} \mathrm{S} 1 \mathrm{~A} \sim \mathrm{S} 5 \mathrm{~A}$ (female) and S11A $\sim \mathrm{S} 15 \mathrm{~A}$ (male) are the results from the spectra in Fig. 1, which lead to the standards (For $\mathrm{Ti}$, see Section 3.2). $[\mathrm{X}]_{\mathrm{HC}}$ and $[\mathrm{X}]_{\mathrm{HO}}$ were observed and calculated from the $[\mathrm{X}]_{\mathrm{S}}$.

serum from the 10 subjects are superimposed by sliding vertically so as to have the same background level, as seen in Fig. 1. All the spectra coincide with each other, except the slightly higher Br peak in one of the 10 spectra (It is due to a little higher background and gives the same value of $[\mathrm{Br}]_{\mathrm{S}}=\log P-\log S$ as those for the other 9 spectra); as seen from Table 1, except $[\mathrm{K}]_{\mathrm{S}}$ for S13A, the 10 spectra give the same concentration for each of the elements $\mathrm{Ca}, \mathrm{Sr}, \mathrm{P}, \mathrm{S}, \mathrm{K}, \mathrm{Cl}$ and $\mathrm{Br}$ under renal control, which are used as the standard values for dried serum $[\mathrm{X}]_{\mathrm{S}}$ by Eq. (2) in this study. These elements have ions in serum and maintain electric neutrality with serum [Protein ${ }^{-}$], i.e., the observed concentration in dried serum corresponds to the number of the ions (atoms) per protein molecule and is under the homeostatic control. The elements, $\mathrm{Cu}, \mathrm{Fe}$ and $\mathrm{Zn}$, with no ions in serum, are more variable in concentration as seen in Table 1. $[\mathrm{X}]_{\mathrm{HC}}$ and $[\mathrm{X}]_{\mathrm{HO}}$ were confirmed by calculation from the serum standards in the following sections.

\subsection{Copper $\mathrm{Cu}$ and Titanium $\mathrm{Ti}$}

Essential elements such as $\mathrm{Cu}, \mathrm{Fe}$, and $\mathrm{Zn}$ exist only bound to serum protein, i.e., $[\mathrm{X}]_{\mathrm{S}}=[\mathrm{X}]_{\mathrm{P}}$ and $[\mathrm{X}]_{\mathrm{I}}=0$. As seen in Fig. 1, XFA for $\mathrm{CuK} \alpha$ at $8 \mathrm{keV}, \mathrm{FeK} \alpha$ at $6.4 \mathrm{keV}$ and $\mathrm{ZnK} \alpha$ at $8.6 \mathrm{keV}$ gave the values we used as standards $\log [\mathrm{Cu}]_{\mathrm{S}}=\log [\mathrm{Cu}]_{\mathrm{P}}=\left([\log P-\log S]_{\mathrm{S}}\right)_{\mathrm{st}}=\log 20, \log [\mathrm{Fe}]_{\mathrm{S}}=$ $\log [\mathrm{Fe}]_{\mathrm{P}}=\log 15$ and $\log [\mathrm{Zn}]_{\mathrm{S}}=\log [\mathrm{Zn}]_{\mathrm{P}}=\log 20$. Since the important elements $\mathrm{Ca}, \mathrm{Sr}, \mathrm{Cl}$, and $\mathrm{Br}$ happen to have their standard of $\log [\mathrm{X}]_{\mathrm{P}}=\log [\mathrm{X}]_{\mathrm{H}}=\log P-\log S=\log 10$ as will be seen later, comparison with these elements will be made by normalizing the observed values $[\log P-\log S]_{\mathrm{H}}$ by the equation

$$
\log [\mathrm{Cu}]_{\mathrm{H}}=[\log P-\log S]_{\mathrm{H}} /\left([\log P-\log S]_{\mathrm{S}}\right)_{\mathrm{st}},
$$

using the above standard $\left([\log P-\log S]_{\mathrm{S}}\right)_{\mathrm{st}}$ for dried serum.

The homeostasis of the metals with $[\mathrm{X}]_{\mathrm{S}}=[\mathrm{X}]_{\mathrm{P}}$ is to some measure achieved by the liver, which excretes their excess into bile; each element's standard $[\mathrm{X}]_{\mathrm{S}}$ level is maintained by both the intake of excess and its excretion, and therefore values less than the standard mean deficiency. When the liver function is deteriorated, their hair $[\mathrm{X}]_{\mathrm{H}}$ level becomes higher than the standard. The lack of correlation of $[\mathrm{X}]_{\mathrm{H}}$ among kinds of the metals suggests that the different parts or functions of the liver are responsible for the different metals. Especially, $\mathrm{Cu}$ and $\mathrm{Ti}$ are sensitive to liver function. 


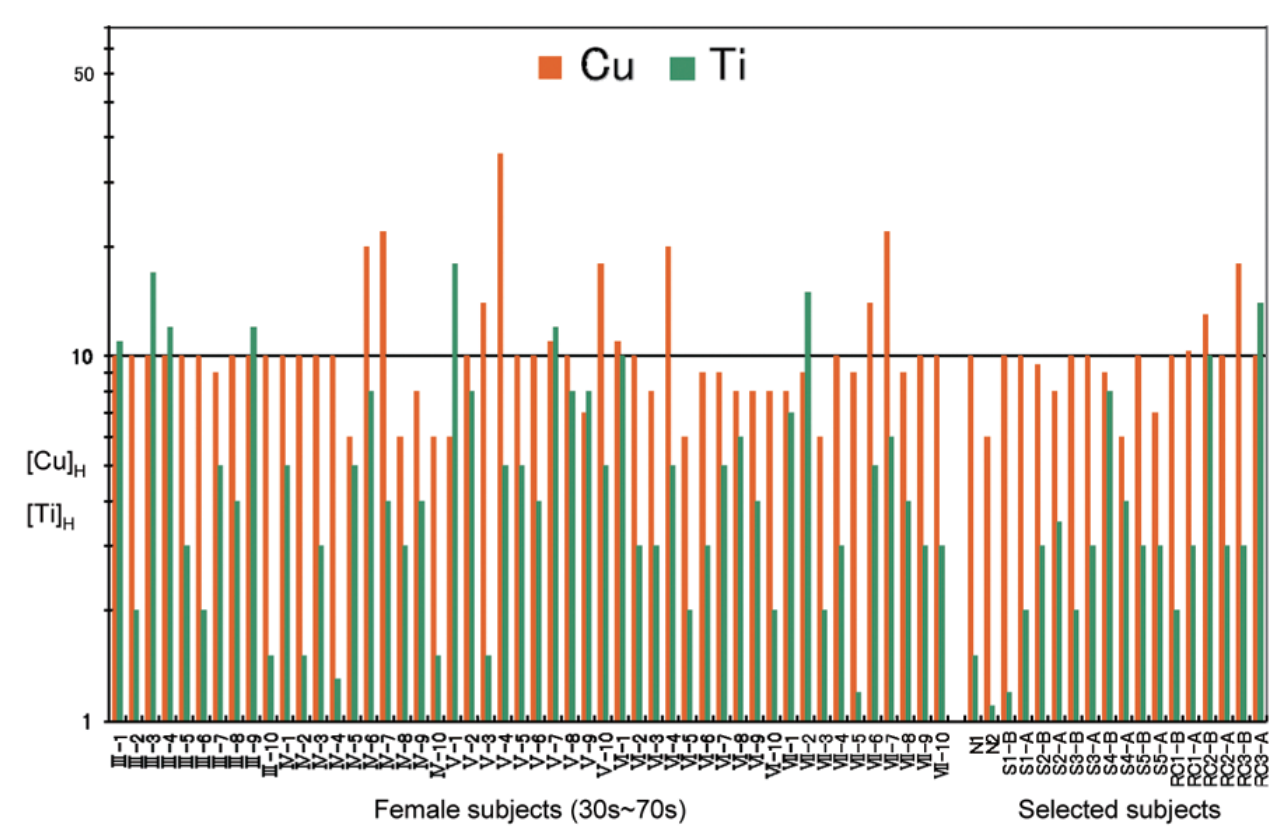

Fig. 2. Hair concentrations $[\mathrm{Cu}]_{\mathrm{H}}$ and $[\mathrm{Ti}]_{\mathrm{H}}$ observed in hair roots for 50 randomly-selected female subjects aged between $30 \mathrm{~s}$ and $70 \mathrm{~s}$. The bar graph is in order of age, and the Roman numerals in the subject labels stand for age period. The subjects labelled N1 to RC3 on the right are related with renal function (See Fig. 3). The essential element Cu shows the homeostasis standard at $[\mathrm{Cu}]_{\mathrm{H}}=10$ by Eq. (3), while Ti has a variety in $[\mathrm{Ti}]_{\mathrm{H}}$ by Eq. (2). The values far over the standard are due to deterioration of the liver function to excrete excess metals into bile which is caused by alcohol injury for III-4, VII-2, and VII- 6 or by the Ca inflows into hepatocytes through gating Ca channels with Ca deficiency as seen for IV-6, IV-7, V-3, V-4, VI-4, VII-7 in comparison with Fig. 3. (Colours are visible in the online version of the article; http://dx.doi.org/10.3233/XST-140439)

Figure 2 shows the $[\mathrm{Cu}]_{\mathrm{H}}$ peak heights normalized by Eq. (3) together with the $[\mathrm{Ti}]_{\mathrm{H}}$ values measured for the hair roots of 50 randomly-selected females aged between their $30 \mathrm{~s}$ and $70 \mathrm{~s}$; the labels for the subjects have Roman numerals which stand for each age period, and the bar graph is in order of age. The similarity of $[\mathrm{Cu}]_{\mathrm{H}}$ can be seen; most of them have the value of the normalized standard $[\mathrm{Cu}]_{\mathrm{H}}=10$ or slightly less than that. Therefore, we can write for both the dried serum and hair standards,

$$
[\mathrm{Cu}]_{\mathrm{S}}=[\mathrm{Cu}]_{\mathrm{P}}=[\mathrm{Cu}]_{\mathrm{H}} \simeq 10,
$$

in the normalized scale by Eq. (3). This result means that the concentrations in dried serum and hair are equal. This can be confirmed by using the concentration data widely available; since serum has a specific gravity of 1.028 and water at $90 \sim 92 \%$, dried $1-\ell$-serum has a weight of $82 \sim 103 \mathrm{~g}$, and the reported serum [Cu] of $17 \mu \mathrm{mol} / \ell$ [7] becomes dried serum concentration of 170 207 $\mu \mathrm{mol} / \mathrm{kg}$, which is in good agreement with the reported hair $\mathrm{Cu}$ concentration of $200 \mu \mathrm{mol} / \mathrm{kg}$ [7]. In conclusion, an element in serum protein behaves as if hair were the same as dried serum. Hair is made with proteins (amino acids) from serum. So it is conceivable that dried serum and hair have the same concentration for each protein-bound element.

So we have

$$
[\mathrm{X}]_{\mathrm{H}}=[\mathrm{X}]_{\mathrm{P}}
$$

for $[X]_{I}=0$ or no ion-channel flux of HM cells. 
Generally, Eq. (5) is valid even if $[\mathrm{X}]_{\mathrm{P}}$ exceeds the standard. For $\mathrm{Cu}$, however, the concentration $[\mathrm{Cu}]_{\mathrm{S}}$ in dried serum was always kept at $[\mathrm{Cu}]_{\mathrm{S}}=10$ even when $[\mathrm{Cu}]_{\mathrm{H}}>10$, i.e., copper in serum is saturated at $[\mathrm{Cu}]_{\mathrm{S}}=10$. Therefore, the few observed high values of $[\mathrm{Cu}]_{\mathrm{H}}>10$ in hair suggest that $\mathrm{Cu}$ (due to the deterioration of liver function) is accommodated into cells in the whole body. $[\mathrm{Cu}]_{\mathrm{H}}$ may therefore be used for diagnosis of liver disease. In this study, high $[\mathrm{Cu}]_{\mathrm{H}}$ and/or high $[\mathrm{Ti}]_{\mathrm{H}}$ values were observed for patients with liver diseases from alcoholic injury to hepatitis; III-4, VII-2, and VII-6 were speculated to be alcoholic injury by the presence of germanium $[\mathrm{Ge}]_{\mathrm{H}}$ peaks in the hair analysis. Germanium has been observed in subjects diagnosed with or with a medical history of alcoholism, but we have not investigated its source or role. (Subject VII-10 is abnormal with an extremely low [Zn $]_{\mathrm{H}}$ value; we have no explanation)

Titanium (Ti) has no solubility in serum. In the normal case, the FX [Ti] peaks by Eq. (2) should be at the background level $\left([\mathrm{Ti}]_{\mathrm{H}}=1\right)$. [Ti $]_{\mathrm{S}}$ is very low, as seen in Fig. 1. Because of the possibility of taking $\mathrm{Ti}$ into the body by wind-blown yellow sand (which often comes to Japan by desertification in the continent.) $[\mathrm{Ti}]_{\mathrm{H}}$ may also be suitable for liver diagnostics.

There are two types; high $[\mathrm{Cu}]_{\mathrm{H}}$ and low $[\mathrm{Ti}]_{\mathrm{H}}$ for IV-7, V-3, VII-7 (Cu type) and $[\mathrm{Ti}]_{\mathrm{H}} \gg 1 \mathrm{vs}$. $[\mathrm{Cu}]_{\mathrm{H}} \leqslant 10$ for VII-2 (Ti type). (Some are Cu \& Ti type).

In summary, deterioration of the liver function appears to cause increases of various metal elements in hair. Most of heavy metals such as $\mathrm{Cr}, \mathrm{Mn}, \mathrm{Ni}, \mathrm{Pb}$, etc. have no solubility in serum and their small spectral peaks are observed in hair, indicating long-lasted Ca channel gating (See Section 3.3).

The samples (N1 to RC3) shown on the right side of Fig. 2 are for special cases related with renal functions, as will be described in the following sections.

\subsection{Calcium Ca and Strontium Sr}

Serum contains $\mathrm{Ca}$ at $[\mathrm{Ca}]_{\mathrm{S}}=[\mathrm{Ca}]_{\mathrm{I}}+[\mathrm{Ca}]_{\mathrm{P}}=8.5 \sim 10.3 \mathrm{mg} / \mathrm{dL}$ with $[\mathrm{Ca}]_{\mathrm{I}}=4.2 \sim 5.0 \mathrm{mg} / \mathrm{dL}$, i.e., $[\mathrm{Ca}]_{\mathrm{I}}=[\mathrm{Ca}]_{\mathrm{P}}(=2.5 \mathrm{mM} / \mathrm{L})$ in the normal case. The Ca ions play an important role as a messenger in the universal cellular signal transduction [8], and therefore the [Ca $]_{I}$ is kept at a nearly constant level by the action of parathyroid cells having $\mathrm{Ca}$ ion sensors "CaSR" [9]. The $[\mathrm{Ca}]_{\mathrm{P}}$ is in an equilibrium with the $[\mathrm{Ca}]_{\mathrm{I}}$ and varies depending upon the hydrogen exponent $(\mathrm{pH})$ of serum; $[\mathrm{Ca}]_{\mathrm{P}}$ decreases with lower $\mathrm{pH}$, acidosis, and increases with alkalosis.

The systematic control to maintain the homeostatic $[\mathrm{Ca}]_{\mathrm{I}}$ in serum has been outlined [8-11]; when serum $[\mathrm{Ca}]_{\mathrm{I}}$ increases, the thyroid gland secretes calcitonin which acts to deposit $\mathrm{Ca}$ on bone. In response to drops in $[\mathrm{Ca}]_{I}$ due to Ca deficiency, parathyroid hormone (PTH) is secreted and mobilizes Ca from the bone into serum. The PTH also acts on kidney to increase reabsorption of $\mathrm{Ca}$ from urine and to activate vitamin D for intestinal Ca absorption. PTH molecules bind with the receptors in cell membrane [12] and produce $\mathrm{Ca}$ channel inflow into the cells (gating channels) [8,11]. In the steady-state growth of hair, the $[\mathrm{Ca}]_{\mathrm{H}}$ in hair must be equal to the influx into the $\mathrm{HM}$ cells from serum, even if $\mathrm{Ca}$ also exists in the cell in reservoirs such as endoplasmic reticulum and mitochondria. Because of the steep increase of PTH secretion with decrease of extracellular $\left[\mathrm{Ca}^{2+}\right]$ (below $2.5 \mathrm{mM} / \mathrm{L}$ [9]), the upper and lower levels of $[\mathrm{Ca}]_{\mathrm{H}}$ in hair should be observed for the gating and closing channels of HM cells, respectively.

These two levels of $[\mathrm{Ca}]_{\mathrm{H}}$ can be seen in Fig. $3 ;[\mathrm{Ca}]_{\mathrm{H}}$ and $[\mathrm{Sr}]_{\mathrm{H}}$ defined by Eq. (2) were measured for the same hair samples as those in Fig. 2. Most of $[\mathrm{Ca}]_{\mathrm{H}}$ values are at $[\mathrm{Ca}]_{\mathrm{H}}=10$ and under (DA type in Section 4.1). Note that the subjects labelled V-3, V-4, VI-4, and VII-7 have a 5-times higher value $[\mathrm{Ca}]_{\mathrm{H}}=50$. Although there are intermediate values for IV-7, VI-6, VII-5, and VII-8, the two levels can be easily recognized at $[\mathrm{Ca}]_{\mathrm{H}}=10$ and $[\mathrm{Ca}]_{\mathrm{H}}=50$. All the young subjects less than 45 , from 


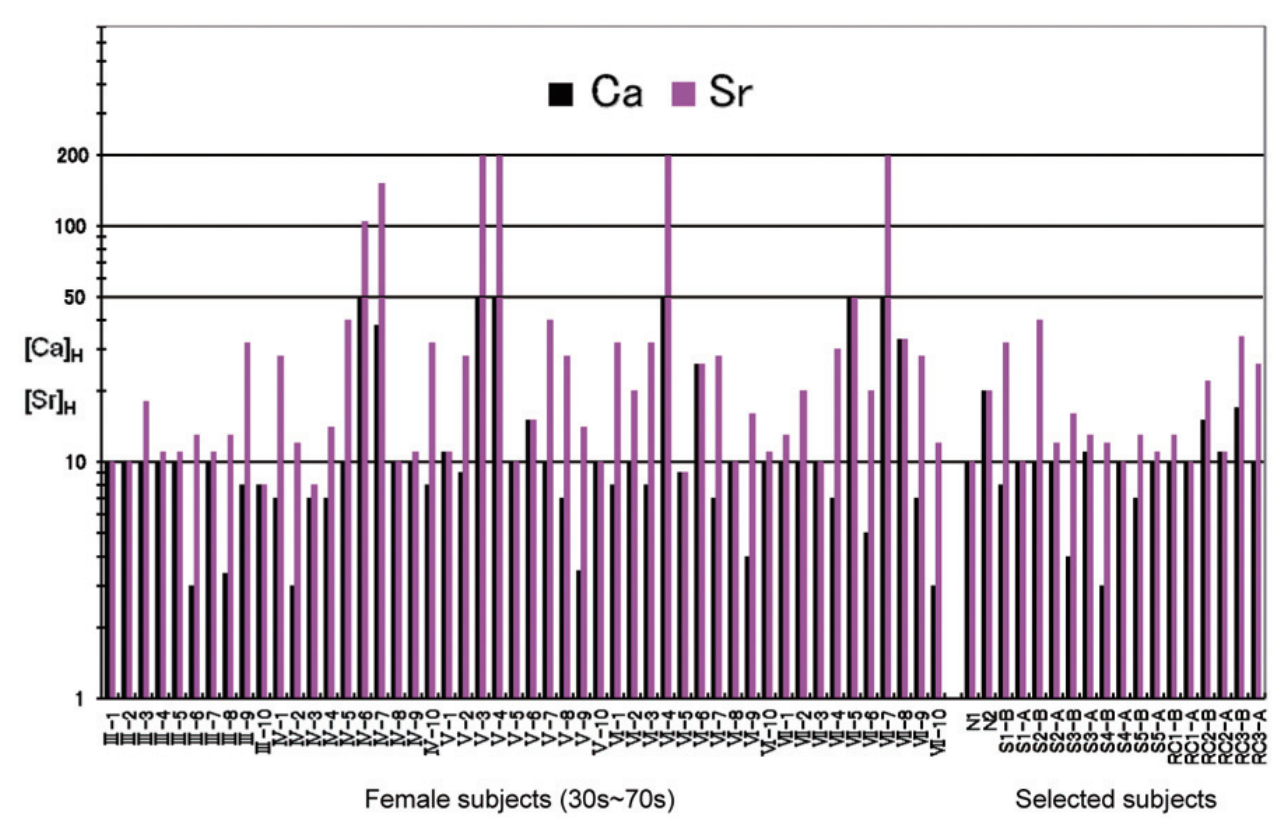

Fig. 3. Hair concentrations $[\mathrm{Ca}]_{\mathrm{H}}$ and $[\mathrm{Sr}]_{\mathrm{H}}$ for the same samples as those in Fig. 2. There are two separated levels for each; the upper level at $[\mathrm{Ca}]_{\mathrm{H}}=50$ [Eq. (6)] and $[\mathrm{Sr}]_{\mathrm{H}}=200$ [Eq. (7)] as seen for V-3, V-4, VI-4 and VII-7 (Ca deficiency) and the lower level at $[\mathrm{Ca}]_{\mathrm{H}} \leqslant 10$ and $[\mathrm{Sr}]_{\mathrm{H}} \leqslant 10$ for most of the subjects. The relations of $[\mathrm{Ca}]_{\mathrm{H}}=[\mathrm{Sr}]_{\mathrm{H}}$ and $[\mathrm{Ca}]_{\mathrm{H}}<[\mathrm{Sr}]_{\mathrm{H}}$ correspond to $\mathrm{Ca}^{2+}$ channel closing and gating of the hair-making cells under the hair root, respectively. The intermediate $[\mathrm{Ca}]_{\mathrm{H}}$ values are seen for V-6, VI-6, VII-5, VII-8 and N2 with channel closing. The inequality $[\mathrm{Ca}]_{\mathrm{H}}<[\mathrm{Sr}]_{\mathrm{H}}$ for the range of $[\mathrm{Ca}]_{\mathrm{H}} \leqslant 10$ is due to store-operated $\mathrm{Ca}$ channel gating, with no exceeding the normal $[\mathrm{Ca}]_{\mathrm{H}}=10$. The effect of taking $900 \mathrm{mg}$ of Ca per day for 2 months is seen for 5 males of S1 S5, labelling "B" and "A" for "before" and "after" the supplementation, respectively. The bars marked $\mathrm{RC} 1 \sim \mathrm{RC} 3$ are for breast-cancer patients showing changes before ("B") and after ("A") an operation to remove cancer. (Colours are visible in the online version of the article; http://dx.doi.org/10.3233/XST-140439)

III-1 to IV-5, have $[\mathrm{Ca}]_{\mathrm{H}} \leqslant 10$. This suggests that the lower level is the healthy standard. For a selected number of subjects, taking a supplement called "Active Absorbable Algal calcium" (3ACa) [12] with $900 \mathrm{mg}$ of Ca per day for 10 days, the upper $[\mathrm{Ca}]_{\mathrm{H}}$ was reduced to a value less than the lower level [6]. It is concluded that the upper level of $[\mathrm{Ca}]_{\mathrm{H}}$ is due to the $\mathrm{Ca}$ ion inflows through channels gating with $\mathrm{Ca}$ deficiency; gating to repeat opening the channels accumulates $\mathrm{Ca}$ in the cell to the maximum level, equal to the serum ion $[\mathrm{Ca}]_{\mathrm{I}}$. In other words, the upper level $[\mathrm{Ca}]_{\mathrm{H}}=50$ is in the equilibrium with the homeostatic serum ion $[\mathrm{Ca}]_{\mathrm{I}}$ through the gating channels of the $\mathrm{HM}$ cells.

Figure 3 also shows that $\mathrm{Ca}$ channel gating due to $\mathrm{Ca}$ deficiency gives a $[\mathrm{Ca}]_{\mathrm{H}}$ near or at the upper level of $[\mathrm{Ca}]_{\mathrm{H}}=50$ and occurs in another range of $[\mathrm{Ca}]_{\mathrm{H}} \leqslant 8$ less than the lower level. The Ca supplementation can quickly shift the upper level into the lower range, so that $[\mathrm{Ca}]_{\mathrm{H}}$ is well separated into the two levels, as seen in Fig. 3. In the latter case, however, long-term $\mathrm{Ca}$ supplementation is required to increase the low $[\mathrm{Ca}]_{\mathrm{H}}$ to the normal $[\mathrm{Ca}]_{\mathrm{H}}=10$. The effect of the 2-month Ca supplementation can be seen for the male subjects labelled S1 S5 on the right side of Fig. 3; compare S4B and S4A taken before and after the supplementation. $\mathrm{Ca}$ on serum protein $\left([\mathrm{Ca}]_{\mathrm{P}}\right)$ is a stockpile for $\mathrm{Ca}$. Since the adult has 4 to 5 litres of blood containing about $200 \mathrm{~g}$ of albumin having 200-mg Ca, typically, it takes a few months to bring the level of $[\mathrm{Ca}]_{\mathrm{P}}=10$ from $[\mathrm{Ca}]_{\mathrm{P}}=3 \sim 4(\mathrm{~S} 3 \mathrm{~B}, \mathrm{~S} 4 \mathrm{~B})$ by supplementation, although a Ca supplement can improve the serum ion $[\mathrm{Ca}]_{\mathrm{I}}$ more rapidly. The channel gating near $[\mathrm{Ca}]_{\mathrm{H}}=50$ and around $[\mathrm{Ca}]_{\mathrm{H}}=10$ is due to the low level of $[\mathrm{Ca}]_{\mathrm{I}}$ and $[\mathrm{Ca}]_{\mathrm{P}}$, respectively. 


\subsubsection{Strontium}

Sr has much the same behaviour as $\mathrm{Ca}$ as a congener alkali metal; $[\mathrm{Sr}]_{\mathrm{S}}=[\mathrm{Sr}]_{\mathrm{P}}+[\mathrm{Sr}]_{\mathrm{I}}$ and $[\mathrm{Sr}]_{\mathrm{P}} \sim$ $[\mathrm{Sr}]_{\mathrm{I}}$. The Ca ion channels in cells act in the same way for Sr ions. The concentration defined by Eq. (2) is that using the standard value of each element for the unit, and the congener proportional relation $[\mathrm{Sr}]_{\mathrm{H}}=[\mathrm{Ca}]_{\mathrm{H}}$ is seen for about a half of the subjects. For the other half, however, the $[\mathrm{Sr}]_{\mathrm{H}}$ is much higher than the $[\mathrm{Ca}]_{\mathrm{H}}$; the difference is 4 times in most of the cases due to a difference in inflow through the gating $\mathrm{Ca}$ ion channels, as will be described later. Therefore, the relation $[\mathrm{Sr}]_{\mathrm{H}}=[\mathrm{Ca}]_{\mathrm{H}}$ means the closing Ca channels in HM cells, i.e., Ca channels are closing for the intermediate values such as V-6, VI-6, VII-5, and VII-8 and for the many cases of $[\mathrm{Ca}]_{\mathrm{H}} \sim 10$.

\subsubsection{The ratio of $[\mathrm{Sr}]_{H} /[\mathrm{Ca}]_{H}$}

The ratio of $[\mathrm{Sr}]_{\mathrm{H}} /[\mathrm{Ca}]_{\mathrm{H}}=4$ is an indication for continuation of $\mathrm{Ca}$ channel gating, Ratios of 1 $<[\mathrm{Sr}]_{\mathrm{H}} /[\mathrm{Ca}]_{\mathrm{H}}<4$ are seen for III-3, IV-4, V-2, VI-2, VII-2 and S5-B, indicating that Ca channel gating and closing occur intermittently (DE type in Section 4.3). The $\mathrm{Sr} / \mathrm{Ca}$ ratio can be helpful in sorting the calcium irregularities into different classes in sections following.

It was found by the scanning measurement along hair shafts that $[\mathrm{Sr}]_{\mathrm{H}}$ lagged behind $[\mathrm{Ca}]_{\mathrm{H}}$ in transition from the lower to the upper level, suggesting a lower conductance of the Ca channels for $\mathrm{Sr}^{2+}$ flows; $[\mathrm{Sr}]_{\mathrm{H}}$ was not able to follow frequent transitions of $[\mathrm{Ca}]_{\mathrm{H}}$ between the two levels. This behaviour is partly responsible for differences of $1<[\mathrm{Sr}]_{\mathrm{H}} /[\mathrm{Ca}]_{\mathrm{H}}<4$ seen for the DE-type. While the upper level of $[\mathrm{Sr}]_{\mathrm{H}}=200\left(\mathrm{~V}-3, \mathrm{~V}-4, \mathrm{VI}-4\right.$ and VII-7) is due to the $\mathrm{Sr}^{2+}$ inflow into cells through long-lasting $\mathrm{Ca}$ channel gating (LD-type in Section 4.3).

\subsubsection{In the case of Ca channel gating in the upper range of $[\mathrm{Ca}]_{H} \gg 10$}

PTH is secreted with Ca deficiency [9] and is systemic to gate the $\mathrm{Ca}^{2+}$ channels in cells in the whole body. The frequent channel gating accumulates $\left[\mathrm{Ca}^{2+}\right]$ to reach the serum $[\mathrm{Ca}]_{\mathrm{I}}$ in $\mathrm{HM}$ cells. (The effect of molecular pumping is minor.) $\mathrm{Ca}$ is incorporated as a pair of two atoms into the hair protein formed in the HM cells [5]. The reaction rate of the pair formation is proportional to the ion collision probability, $\left\{[\mathrm{Ca}]_{I}\right\}^{2}$, in the HM cell. The dissociation rate of Ca pair atoms in the hair protein is proportional to twice the $[\mathrm{Ca}]_{\mathrm{HO}}$ because the dissociation of one calcium-bound protein molecule means the production of two calcium ions. In the chemical equilibrium, both the rates must be equal, i.e., $2 r[\mathrm{Ca}]_{\mathrm{HO}}=q\left\{[\mathrm{Ca}]_{\mathrm{I}}\right\}^{2}$, where $r$ and $q$ are the proportional constants. We have $[\mathrm{Ca}]_{\mathrm{HO}}=(1 / 2)(q / r)[\mathrm{Ca}]_{\mathrm{I}}^{2}$. Using the $[\mathrm{Ca}]_{\mathrm{I}}(=$ 10 ) for dried serum, $q$ and $r$ are equal, $q=r$. This implies that the processes for the pair formation and dissociation are the same. It is envisaged that the protein molecules to be incorporated into the hair are formed in the HM cell and the relation

$$
[\mathrm{Ca}]_{\mathrm{HO}}=(1 / 2)[\mathrm{Ca}]_{\mathrm{I}}^{2} \text {. }
$$

holds between the hair protein and cytosol. It is noteworthy that $[\mathrm{Ca}]_{\mathrm{HO}}$ is in the equilibrium with serum $[\mathrm{Ca}]_{\mathrm{I}}$; as have been seen in Fig. 3, V-3, V-4, VI-4, and VII-7 are at the equal height of $[\mathrm{Ca}]_{\mathrm{HO}}=$ $(1 / 2)(10)^{2}=50$ by Eq. (6) with the $[\mathrm{Ca}]_{\mathrm{I}}=10$ regulated strictly. $\left([\mathrm{Ca}]_{\mathrm{H}}=50\right.$ is the maximum in this study except cases of hypercalcemia.)

Figure 3 shows the $[\mathrm{Sr}]_{\mathrm{H}}$ compared with the $[\mathrm{Ca}]_{\mathrm{H}}$ for each subject. It is seen from IV-7, V-3, V-4, VI-4, and VII-7 that the upper $[\mathrm{Sr}]_{\mathrm{H}}$ level is much higher than that of $[\mathrm{Ca}]_{\mathrm{HO}}$, i.e., $[\mathrm{Sr}]_{\mathrm{HO}}=200$ against $[\mathrm{Ca}]_{\mathrm{HO}}=50$. This upper level $[\mathrm{Sr}]_{\mathrm{HO}}$ is due to $\mathrm{Sr}^{2+}$ inflows through the gating $\mathrm{Ca}^{2+}$ channels of $\mathrm{HM}$ cells. By taking into account $[\mathrm{Sr}]_{\mathrm{S}}=[\mathrm{Sr}]_{\mathrm{I}}+[\mathrm{Sr}]_{\mathrm{P}}=20$, we obtain

$$
[\mathrm{Sr}]_{\mathrm{HO}}=(1 / 2)\left\{[\mathrm{Sr}]_{\mathrm{P}}+[\mathrm{Sr}]_{\mathrm{I}}\right\}^{2} \text {, }
$$


i.e., the total $[\mathrm{Sr}]_{\mathrm{S}}$ in serum contributes to the hair concentration. This suggests that the Sr exists only on the protein in the cell. Equation (7) gives the ratio $[\mathrm{Sr}]_{\mathrm{HO}} /[\mathrm{Ca}]_{\mathrm{HO}}=4$ using Eq. (6) and $[\mathrm{Ca}]_{\mathrm{I}}=[\mathrm{Sr}]_{\mathrm{I}}=$ $[\mathrm{Sr}]_{\mathrm{P}}$ with the definition by Eq. (2). (For mouse, $[\mathrm{Sr}]_{\mathrm{HO}}=(1 / 2)[\mathrm{Sr}]_{\mathrm{I}}^{2}$ ).

\subsubsection{In the case of Ca channel closing at the lower level $[\mathrm{Ca}]_{H}=10$}

All the hair samples from the 10 subjects with Ca supplementation showed the standard $[\mathrm{Ca}]_{\mathrm{H}}=10$; the $[\mathrm{Ca}]_{\mathrm{S}}=20$ (Table 1) for dried serum is twice that for the hair. It holds for the normal case that $[\mathrm{Ca}]_{\mathrm{I}}=[\mathrm{Ca}]_{\mathrm{P}}=[\mathrm{Ca}]_{\mathrm{H}}$. This means equality in the chemical potential for Ca between the liquid and protein. With closing ion channels, only the serum protein having the half of $[\mathrm{Ca}]_{\mathrm{S}}$ can provide $\mathrm{Ca}$ to be incorporated into the $\mathrm{HM}$ cells. So the hair concentration $[\mathrm{Ca}]_{\mathrm{HC}}$ in the case of closing ion channels is

$$
[\mathrm{Ca}]_{\mathrm{HC}}=[\mathrm{Ca}]_{\mathrm{P}}
$$

Similarly for $\mathrm{Sr}$ with $\mathrm{Ca}$ channel closing, we have

$$
[\mathrm{Sr}]_{\mathrm{HC}}=[\mathrm{Sr}]_{\mathrm{P}}=[\mathrm{Ca}]_{\mathrm{P}}=[\mathrm{Ca}]_{\mathrm{HC}} .
$$

from Eq. (5). This relation $[\mathrm{Sr}]_{\mathrm{HC}}=[\mathrm{Ca}]_{\mathrm{HC}}$ at the lower level $[\mathrm{Ca}]_{\mathrm{HC}}=10$ is seen for III-1, III-2, III-4, III-5, III-7, III-10, IV-8, IV-9, V-1, V-5, V-10, VI-5, VI-8, VI-10, VII-1, and VII-3 in Fig. 3. Also, $[\mathrm{Sr}]_{\mathrm{HC}}=[\mathrm{Ca}]_{\mathrm{HC}}>10$ is seen for V-6, VI-6, VII-5, and VII-8 (DO type in Section 4.2). The relation $[\mathrm{Sr}]_{\mathrm{H}}=[\mathrm{Ca}]_{\mathrm{H}}$ at any level is an indication of Ca channel closing, and $[\mathrm{Sr}]_{\mathrm{H}}=[\mathrm{Ca}]_{\mathrm{H}}=10$ is typical for healthy subjects.

Here the absolute standard values of $[\mathrm{Ca}]$ in hair are estimated from the serum $[\mathrm{Ca}]$ in the same way as $[\mathrm{Cu}]_{\mathrm{H}}$; serum protein $[\mathrm{Ca}]$ of $5 \mathrm{mg} / \mathrm{dL}$ turns out to be $[\mathrm{Ca}]_{\mathrm{P}}=[\mathrm{Ca}]_{\mathrm{HC}}=0.49 \sim 0.6 \mathrm{mg} / \mathrm{g}$ and $[\mathrm{Ca}]_{\mathrm{HO}}=5 \times[\mathrm{Ca}]_{\mathrm{HC}}=2.5 \sim 3.0 \mathrm{mg} / \mathrm{g}$. Using the total serum $[\mathrm{Sr}]_{\mathrm{S}}=30.9 \pm 11.7 \mu \mathrm{g} / \mathrm{L}[13]$, we obtain $[\mathrm{Sr}]_{\mathrm{HC}}=0.17 \mu \mathrm{g} / \mathrm{g}$ and $[\mathrm{Sr}]_{\mathrm{HO}}=3.3 \mu \mathrm{g} / \mathrm{g}$.

\subsubsection{Ca channel gating in the lower range $[\mathrm{Ca}]_{H}<10$}

The same difference of $[\mathrm{Sr}]_{\mathrm{H}} /[\mathrm{Ca}]_{\mathrm{H}}=4$ between $[\mathrm{Sr}]_{\mathrm{H}}$ and $[\mathrm{Ca}]_{\mathrm{H}}$ appears for $[\mathrm{Ca}]_{\mathrm{H}} \leqslant 10$, as seen for III-6, III-8, III-9, IV-1, IV-2, IV-5, IV-10, V-2, V-7, V-8, V-9, VI-1, VI-3, VI-7, VI-9, VII-4, VII-6, VII-9 and VII-10 in Fig. 3. However, all of them have $[\mathrm{Ca}]_{\mathrm{H}} \leqslant 10$. Their $[\mathrm{Ca}]_{\mathrm{H}}$ values never exceed the standard level of $[\mathrm{Ca}]_{\mathrm{H}}=10$. The Ca channel gating occurs so as to keep the $[\mathrm{Ca}]_{\mathrm{H}}$ at the normal. It was observed by scanning the $50-\mu \mathrm{m}$ width $\mathrm{x}$-ray beam along the hair that the $[\mathrm{Ca}]_{\mathrm{H}}$ was kept at the normal despite the variation of the $[\mathrm{Sr}]_{\mathrm{H}}$. Therefore, the $\mathrm{HM}$ cells have store-operated $\mathrm{Ca}^{2+}$ channels; their gating is not by PTH but by some kind of intracellular signals. With the PTH-operated channels closed, $\mathrm{Ca}$ in the cells is supplied by the serum protein having $\mathrm{Ca}$. When the stored $\mathrm{Ca}$ on the protein is decreased so as to give $[\mathrm{Ca}]_{\mathrm{H}}<8$, the store-operated $\mathrm{Ca}^{2+}$ channels are put in action. The subjects taken as the example are in a deviation toward acidosis with $[\mathrm{Cl}]_{\mathrm{H}}=[\mathrm{Br}]_{\mathrm{H}} \geqslant 22$, except V-7, VI-1 and VII-4 deviated toward alkalosis with a low $[\mathrm{Cl}]_{\mathrm{H}}$ (Fig. 4), depending upon the serum [PTH] (See Section 4.3). Subjects in this example show acidosis or alkalosis, not neutrality.

\subsection{Chlorine and Bromine}

Serum contains $\mathrm{Cl}$ and $\mathrm{Br}$ as atoms in the protein and ions in the liquid, i.e.

$$
\begin{aligned}
& {[\mathrm{Cl}]_{\mathrm{S}}=[\mathrm{Cl}]_{\mathrm{P}}+[\mathrm{Cl}]_{\mathrm{I}}} \\
& {[\mathrm{Br}]_{\mathrm{S}}=[\mathrm{Br}]_{\mathrm{P}}+[\mathrm{Br}]_{\mathrm{I}},}
\end{aligned}
$$




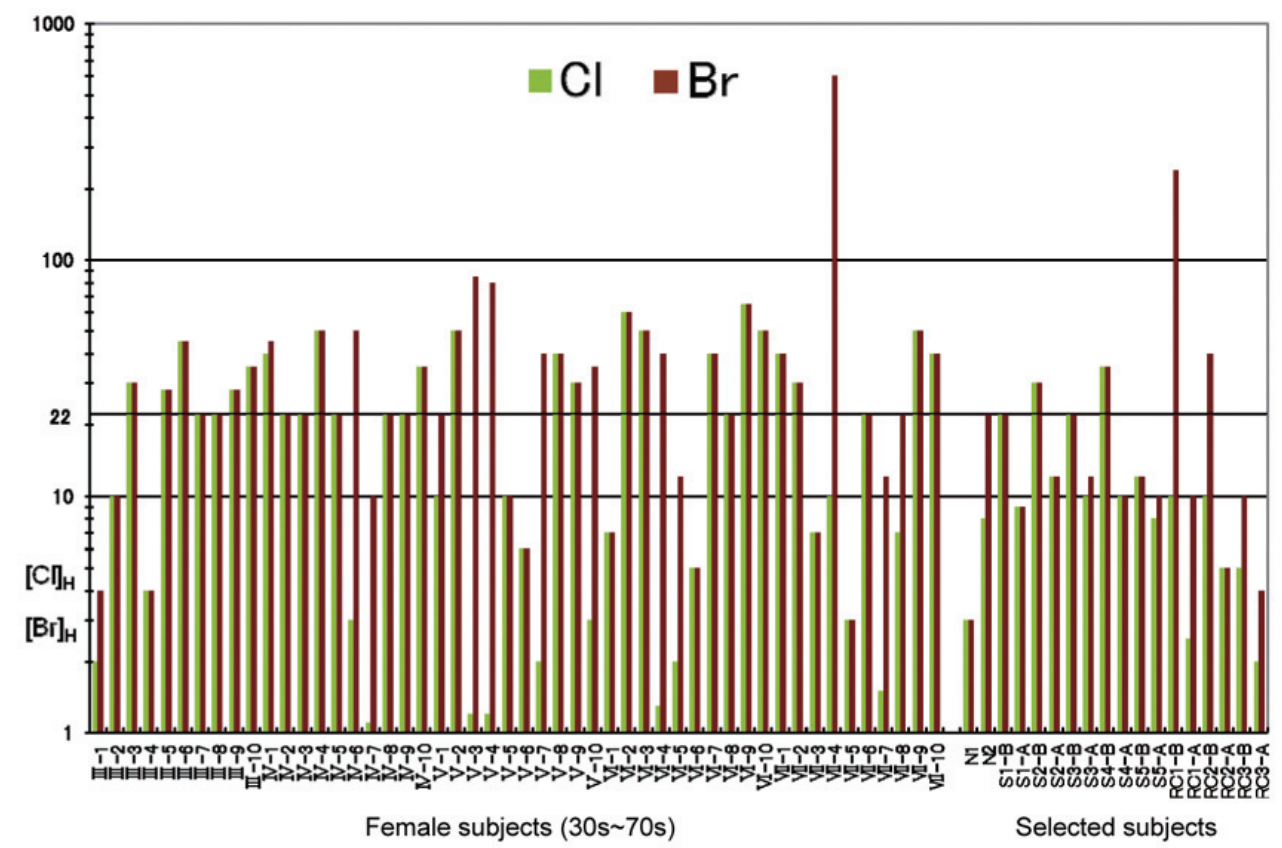

Fig. 4. Hair concentrations $[\mathrm{Cl}]_{\mathrm{H}}$ and $[\mathrm{Br}]_{\mathrm{H}}$ for the same samples as those in Fig. 2. Both the lower (standard) and upper level are seen at $[\mathrm{Cl}]_{\mathrm{H}}=[\mathrm{Br}]_{\mathrm{H}}=[\mathrm{Cl}]_{\mathrm{P}}=[\mathrm{Br}]_{\mathrm{P}}=10$ for $\mathrm{Cl}^{-}$channel closing and at $[\mathrm{Cl}]_{\mathrm{H}}=[\mathrm{Br}]_{\mathrm{H}}=22$ for channel gating by Eq. (12), respectively. It is seen from $\mathrm{S} 2 \sim \mathrm{S} 4$ that the $\mathrm{Ca}$ supplementation recovers $[\mathrm{Cl}]_{\mathrm{H}}=[\mathrm{Br}]_{\mathrm{H}}>22$ deviated to acidosis with the Ca deficiency, having $[\mathrm{Ca}]_{\mathrm{H}} \ll 10$ in Fig. 3. The inequality $[\mathrm{Cl}]_{\mathrm{H}}<[\mathrm{Br}]_{\mathrm{H}}$ as seen for IV-6, IV-7, V-3, V-4, etc. indicates alkalosis with deterioration of the chloride shift caused by $\mathrm{Ca}$ inflows into erythrocytes through the gating Ca channels (Compare with Fig. 3). The extremely high $[\mathrm{Br}]_{\mathrm{H}}$ is due to a tendency to compensate the $\mathrm{Cl}$ deficiency with $\mathrm{Br}$. (Colours are visible in the online version of the article; http://dx.doi.org/10.3233/XST-140439)

although almost all of $\mathrm{Cl}$ and $\mathrm{Br}$ exist as ions in serum. In general, $\mathrm{Cl}$ and $\mathrm{Br}$ have the congener proportional relation. Similarly to the case of $\mathrm{Ca}$ and $\mathrm{Sr}$, we have

$$
[\mathrm{Cl}]=[\mathrm{Br}]
$$

for both the concentrations in dried serum and hair obtained by Eq. (2).

Figure 4 shows $[\mathrm{Cl}]_{\mathrm{H}}$ and $[\mathrm{Br}]_{\mathrm{H}}$ values by Eq. (2) for the same hair samples as those in Fig. 2. Equation (10) holds for most of the hair samples, as seen in [6], i.e., $[\mathrm{Cl}]_{\mathrm{H}}=[\mathrm{Br}]_{\mathrm{H}}$, except cases of low $[\mathrm{Cl}]_{\mathrm{H}}$ values. There are two homeostatic levels; the upper at $[\mathrm{Cl}]_{\mathrm{H}}=[\mathrm{Br}]_{\mathrm{H}}=22$ and the lower at $[\mathrm{Cl}]_{\mathrm{H}}=[\mathrm{Br}]_{\mathrm{H}}=10[6]$, which can be attributed to gating and closing of channels acting for these ions.

\subsubsection{In the case of Cl channel gating}

The ion concentration in cells is considered to be equal to that of serum $[\mathrm{Cl}]_{\mathrm{I}}=[\mathrm{Br}]_{\mathrm{I}}=250$ (Table 1). Comparison of the values $[\mathrm{Cl}]_{\mathrm{HO}}$ and $[\mathrm{Cl}]_{\mathrm{S}} \sim[\mathrm{Cl}]_{\mathrm{I}}\left([\mathrm{Br}]_{\mathrm{HO}}\right.$ and $\left.[\mathrm{Br}]_{\mathrm{S}} \sim[\mathrm{Br}]_{\mathrm{I}}\right)$ leads to the relation [6],

$$
[\mathrm{Cl}]_{\mathrm{HO}}^{2}=2[\mathrm{Cl}]_{\mathrm{I}}
$$

Since $[\mathrm{Cl}]_{\mathrm{HO}}^{2}=22 \times 22=484$ and $[\mathrm{Cl}]_{\mathrm{S}} \sim[\mathrm{Cl}]_{\mathrm{I}}=250$, Eq. (11) holds within the margin of error. We rewrite Eq. (11) as

$$
[\mathrm{Cl}]_{\mathrm{HO}}=\left\{2[\mathrm{Cl}]_{\mathrm{I}}\right\}^{1 / 2}
$$


Similarly to the case of Eq. (6), Eq. (11) implies an equilibrium relation between the hair protein and cytosol in the $\mathrm{HM}$ cells where $\mathrm{Cl}$ exists as single and pair atoms, respectively. In other words, the intracellular $\mathrm{Cl}$ is assumed to occur as un-ionized pair atoms at the concentration of serum $\mathrm{Cl}$ ions (equal chemical potential).

The normal $[\mathrm{Cl}]$ in serum is known as $[\mathrm{Cl}]_{\mathrm{S}}=103 \mathrm{mM} / \mathrm{L}$, corresponding to $[\mathrm{Cl}]_{\mathrm{S}}=250$ in dried serum by Eq. (2). Metabolic alkalosis occurs with a serum [Cl] less than $97 \mathrm{mM} / \mathrm{L}$ accompanied by the increase of $\mathrm{HCO}_{3}^{-}$, and acidosis results in $[\mathrm{Cl}]>109 \mathrm{mM} / \mathrm{L}$. Both deviate from the normal by less than $6 \%$. Comparison in $[\mathrm{Cl}]$ and $[\mathrm{Br}]$ between dried serum and hair showed that the hair upper level of $[\mathrm{Cl}]_{\mathrm{HO}}=22$ and $[\mathrm{Br}]_{\mathrm{HO}}=22$ accompanied gating of the ion channels due to the acidosis. This $\mathrm{Cl}$ channel gating is considered to take place so as to shepherd the excess $[\mathrm{Cl}]$ in serum into cells, to synchronize with the $\mathrm{Cl}$ transport into erythrocytes in the chloride shift [14].

\subsubsection{In the case of Cl channel closing}

Only $\mathrm{Cl}$ and $\mathrm{Br}$ in serum protein are incorporated into the $\mathrm{HM}$ cells. According to Eq. (5) we have, similarly,

$$
[\mathrm{Cl}]_{\mathrm{HC}}=[\mathrm{Cl}]_{\mathrm{P}}=[\mathrm{Br}]_{\mathrm{P}}=[\mathrm{Br}]_{\mathrm{HC}}
$$

Some of the hair samples in Fig. 4 show the normal $[\mathrm{Cl}]_{\mathrm{HC}}=[\mathrm{Br}]_{\mathrm{HC}}=10$. By Eq. (13) serum protein $[\mathrm{Cl}]_{\mathrm{P}}$ can be obtained by measurement of hair $[\mathrm{Cl}]_{\mathrm{HC}}\left(\right.$ or $\left.[\mathrm{Br}]_{\mathrm{HC}}\right)$; since $[\mathrm{Cl}]_{\mathrm{HC}} /[\mathrm{Cl}]_{\mathrm{S}}=10 / 250,[\mathrm{Cl}]_{\mathrm{P}}$ having $4 \%$ of $[\mathrm{Cl}]_{S}$ enters the cells. This can be compared favourably with the intracellular/extracellular $\mathrm{Cl}$ mol ratio of 5/108 in the Gamble gram [15] as the normal.

\subsubsection{Equality and inequality between $[\mathrm{Cl}]_{H}$ and $[\mathrm{Br}]_{H}$}

The $[\mathrm{Cl}]_{\mathrm{S}}$ is controlled by the renal action depending upon [PTH] in serum [10]. Therefore, the normal of $[\mathrm{Cl}]_{\mathrm{HC}}=[\mathrm{Br}]_{\mathrm{HC}}=10$ is achieved with low $[\mathrm{PTH}]$ in serum, as seen from $[\mathrm{Cl}]_{\mathrm{HC}}$ and $[\mathrm{Br}]_{\mathrm{HC}}$ values for S1 S5 before and after the Ca supplementation in Fig. 4.

Serum deviations to acidosis and alkalosis result in hair $[\mathrm{Cl}]_{\mathrm{H}}=[\mathrm{Br}]_{\mathrm{H}} \gg 10$ and $[\mathrm{Cl}]_{\mathrm{H}}=[\mathrm{Br}]_{\mathrm{H}} \ll$ 10 , respectively.

The inequality $[\mathrm{Cl}]_{\mathrm{H}} \ll[\mathrm{Br}]_{\mathrm{H}}$ is always associated with $\mathrm{Ca}$ channel gating as seen from comparison of Figs 3 and 4. The examples are IV-6, IV-7, V-3, V-4, VI-4, VII-7, etc. Ca channel gating causes $\mathrm{Ca}$ inflows into erythrocytes resulting in deterioration of their function in the chloride shift to keep the serum $\mathrm{pH}$ normal. It was confirmed by the serum samples for the observed low $[\mathrm{Cl}]_{\mathrm{H}} \ll 10$ that the $[\mathrm{Cl}]_{\mathrm{S}}$ was slightly low to be alkalosis with $[\mathrm{Cl}]_{\mathrm{S}}=220$ (the normal: $[\mathrm{Cl}]_{\mathrm{S}}=250$ ); hair $[\mathrm{Cl}]_{\mathrm{H}}$ is much more sensitive to $\mathrm{Cl}$ deficiency than the serum $[\mathrm{Cl}]_{S}$.

There are two types for the alkalosis of the inequality $[\mathrm{Cl}]_{\mathrm{H}} \ll[\mathrm{Br}]_{\mathrm{H}}$ : one has a low $[\mathrm{Cl}]_{\mathrm{H}}<10$ with the normal $[\mathrm{Br}]_{\mathrm{H}}=10$ such as IV-7 and VII-7, i.e., $[\mathrm{Cl}]_{\mathrm{H}}=[\mathrm{Cl}]_{\mathrm{P}}<[\mathrm{Br}]_{\mathrm{P}}=[\mathrm{Br}]_{\mathrm{H}}=10([\mathrm{Cl}]$ and $[\mathrm{Br}]$ are independent), and the other shows a low $[\mathrm{Cl}]_{\mathrm{H}}<10$ and a high $[\mathrm{Br}]_{\mathrm{H}}>10$ as seen for $\mathrm{V}-3$ and $\mathrm{V}-4$, where the lower $[\mathrm{Cl}]_{S}$ is compensated with the higher $[\mathrm{Br}]_{S}$. Actually, compensation is restricted by the large difference in normal concentration, $[\mathrm{Cl}]_{\mathrm{S}}=103 \mathrm{mM} / \mathrm{L}$ and $[\mathrm{Br}]_{\mathrm{S}}=60 \mu \mathrm{M} / \mathrm{L}$ [7], and the sum of $[\mathrm{Cl}]_{\mathrm{S}}+[\mathrm{Br}]_{\mathrm{S}}$ should be still so low as to cause alkalosis. The low $[\mathrm{Cl}]_{\mathrm{P}}=[\mathrm{Cl}]_{\mathrm{H}}$ is compensated to some extent with the higher $[\mathrm{Br}]_{\mathrm{P}}=[\mathrm{Br}]_{\mathrm{H}}$ resulting in the inequality $[\mathrm{Cl}]_{\mathrm{H}}=[\mathrm{Cl}]_{\mathrm{P}}<10<[\mathrm{Br}]_{\mathrm{P}}=[\mathrm{Br}]_{\mathrm{H}}$. A typical example is VII-4; the $[\mathrm{Cl}]_{\mathrm{H}}$ is low, and the $[\mathrm{Br}]_{\mathrm{H}}$ is extremely high.

A possible explanation is that the proportionality of $[\mathrm{Cl}]=[\mathrm{Br}]$ in dried serum and hair is lost with the $\mathrm{Ca}$ inflows into erythrocytes through their gating Ca channels (LD type in Section 4.3) which deteriorate the function of the chloride shift. This results in the low $[\mathrm{Cl}]_{\mathrm{S}}$ of alkalosis and $[\mathrm{Cl}]_{\mathrm{S}}<[\mathrm{Br}]_{\mathrm{S}}$. There are 


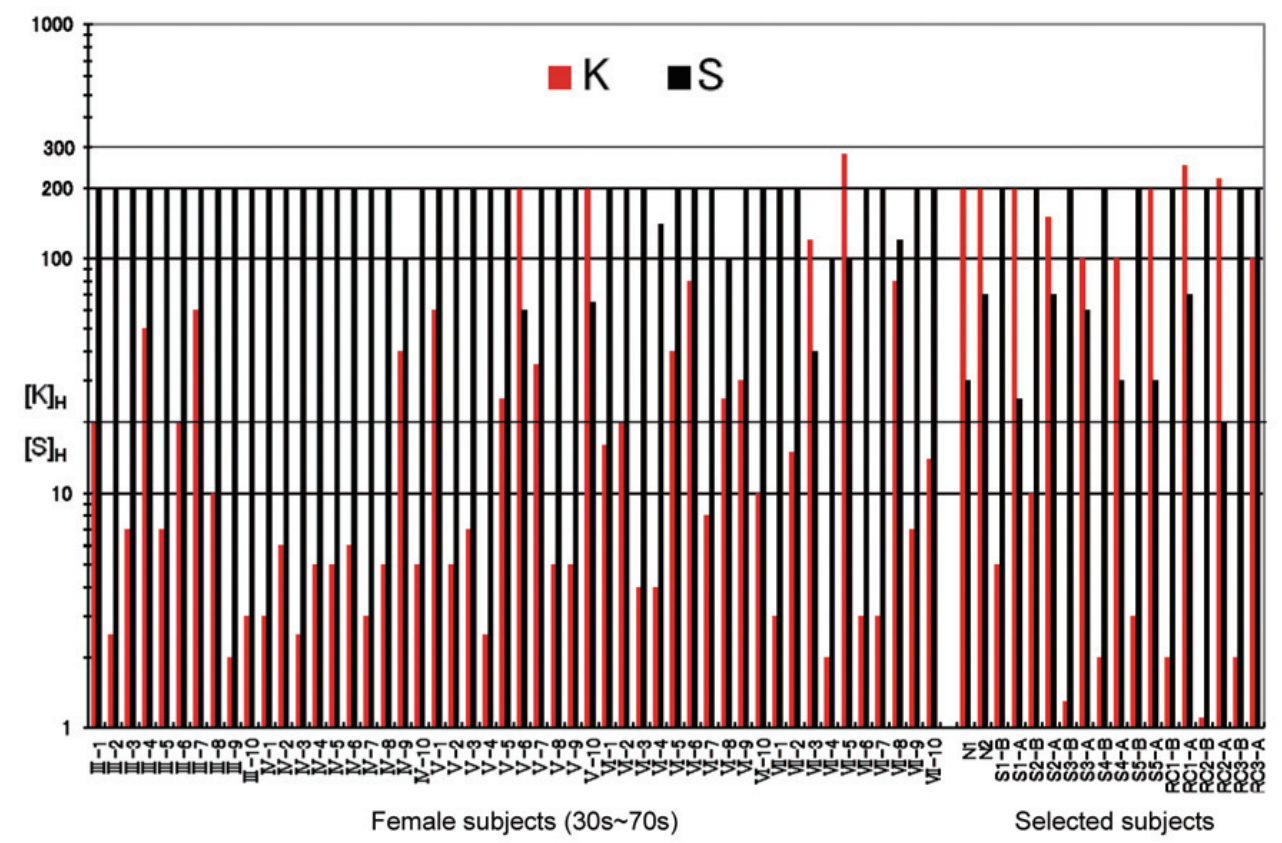

Fig. 5. Hair concentrations $[\mathrm{K}]_{\mathrm{H}}$ and $[\mathrm{S}]_{\mathrm{H}}$ for the same samples as those in Fig. 2. As seen from $\mathrm{S} 1 \sim \mathrm{S} 5$, the Ca supplementation produces the normal value $[\mathrm{K}]_{\mathrm{H}}=200 \sim 300$ and changes $[\mathrm{S}]_{\mathrm{H}}$ from the upper level at $[\mathrm{S}]_{\mathrm{H}}=200[\mathrm{Eq}$. (15)] to the lower level at $[S]_{\mathrm{H}}=20$ (normal), suggesting existence of sulphate ion channels. Most of the 50 subjects have $[\mathrm{S}]_{\mathrm{H}}=200$ and $[\mathrm{K}]_{\mathrm{H}} \leqslant 10$; the higher $[\mathrm{K}]_{\mathrm{H}}$ is, the lower $[\mathrm{S}]_{\mathrm{H}}$ is. PTH inhibits $\mathrm{H}^{+} / \mathrm{Na}^{+}$-exchange and $\mathrm{Na}^{+}$-anion cotransport in renal proximal tubular cells, resulting in increase of serum $\left[\mathrm{H}^{+}\right]$causing exchange $\mathrm{K}^{+} / \mathrm{H}^{+}$in cells and a low sulphate ion concentration in serum responsible for gating sulphate ion channels, respectively. (Colours are visible in the online version of the article; http://dx.doi.org/10.3233/ XST-140439)

two types of the alkalosis, "compensation type" and "independent type". In the former, $\mathrm{Cl}$ and $\mathrm{Br}$ have the same behaviour, and the sum of $[\mathrm{Cl}]_{\mathrm{S}}+[\mathrm{Br}]_{\mathrm{S}}$ is under homeostasis (renal control). The independent type has the $[\mathrm{Br}]_{\mathrm{H}}=10$, indicating that the $[\mathrm{Cl}]_{\mathrm{S}}$ is under homeostasis with the natural ratio of $\mathrm{Br} / \mathrm{Cl}$, with no transport of $\mathrm{Br}$ across the erythrocyte membrane.

Using the total serum $[\mathrm{Cl}]_{\mathrm{S}}=10 \mathrm{mM} / \mathrm{dL}$ and $[\mathrm{Br}]_{\mathrm{S}}=6 \mu \mathrm{M} / \mathrm{dL}$ [7], the lower and upper level are calculated to be $[\mathrm{Cl}]_{\mathrm{HC}}=1.7 \mathrm{mg} / \mathrm{g},[\mathrm{Cl}]_{\mathrm{HO}}=3.8 \mathrm{mg} / \mathrm{g}$ and $[\mathrm{Br}]_{\mathrm{HC}}=2.2 \mu \mathrm{g} / \mathrm{g},[\mathrm{Br}]_{\mathrm{HO}}=4.8 \mu \mathrm{g} / \mathrm{g}$.

\subsection{Potassium}

Serum $\mathrm{K}$ is ionic, i.e., $[\mathrm{K}]_{\mathrm{S}}=[\mathrm{K}]_{\mathrm{I}}$ and $[\mathrm{K}]_{\mathrm{P}}=0$. About $98 \%$ of $\mathrm{K}$ in the whole body exists inside cells. In contrast, $\mathrm{Na}$ exists mainly outside cells, and the extracellular $\left[\mathrm{Na}^{+}\right]$is nearly equal to the intracellular $\left[\mathrm{K}^{+}\right]$. Cells have molecular pumps $\mathrm{Na}^{+} / \mathrm{K}^{+}$-ATPase to pump $\mathrm{Na}^{+}$out and $\mathrm{K}^{+}$in simultaneously. There are also $\mathrm{Na}^{+}$and $\mathrm{K}^{+}$channels in the cell membrane. Since the XFA has too low a sensitivity to Na, only $\mathrm{K}$ was measured.

Figure 5 shows $[K]_{\mathrm{H}}$ values observed for the same samples as those in Fig. 2 . The $[\mathrm{K}]_{\mathrm{H}}$ values by Eq. (2) vary in a wide rang of $[\mathrm{K}]_{\mathrm{H}} \sim 1$ to 300 . In Fig. 5 (S1 S5), Ca supplementation changes $[\mathrm{K}]_{\mathrm{H}}$ from low values to the normal high values of $[\mathrm{K}]_{\mathrm{H}} \geqslant 100$ and shows that the low $[\mathrm{K}]_{\mathrm{H}}$ values are due to Ca deficiency.

The maximum value (as high as $[\mathrm{K}]_{\mathrm{H}}=300$ ) is the standard and can be reached by pumping $\mathrm{K}$ ions $\left(\mathrm{Na}^{+} / \mathrm{K}^{+}\right.$-ATPase) from the extracellular fluid into the $\mathrm{HM}$ cells with $\mathrm{K}^{+}$-channel closing. This standard 
$[\mathrm{K}]_{\mathrm{H}}$ value can be explained using the Gamble gram [15] which gives the relation between serum and cell ion concentrations as the standard. First, the concentrations per litter in the Gamble gram [15] should be converted into those of dried serum, dried cell and hair defined by Eq. (2). Since the main component of dried serum is protein, dried serum $[\mathrm{K}]_{\mathrm{S}}$ and cell $[\mathrm{K}]_{\mathrm{C}}\left(=[\mathrm{K}]_{\mathrm{CI}}\right)$ are proportional to the numbers of ions per protein molecule, $\left[\mathrm{K}^{+}\right] /\left[\right.$Protein $\left.^{-}\right](=5 / 16)$ in serum and $\left[\mathrm{K}^{+}\right] /\left[\left[\right.\right.$Protein $\left.^{-}\right](=157 / 71)$ in cell using the Gamble gra [15], respectively. With $[\mathrm{K}]_{\mathrm{C}} /[\mathrm{K}]_{\mathrm{S}}=(157 / 71) /(5 / 16)=7.08$ and $[\mathrm{K}]_{\mathrm{S}}=40$ from Table 1, we have $[\mathrm{K}]_{\mathrm{C}}=7.08 \times 40=283$. This values is in good agreement with $[\mathrm{K}]_{\mathrm{H}}=300$ observed, indicating that hair $[\mathrm{K}]_{\mathrm{H}}$ values give intracellular concentrations; in general $[\mathrm{K}]_{\mathrm{H}}=[\mathrm{K}]_{\mathrm{C}}$ (dried).

Many of the subjects in Fig. 5 have $[\mathrm{K}]_{\mathrm{H}}$ values much lower than the standard; their intracellular $[\mathrm{K}]_{\mathrm{C}}$ is low due to Ca deficiency. As mentioned previously, PTH inhibits the $\mathrm{H}^{+} / \mathrm{Na}^{+}$exchange in renal proximal convoluted tubular cells to excrete $\mathrm{H}^{+}[10]$, resulting in increase of serum $\left[\mathrm{H}^{+}\right]$. This hydrogen flows into cells and causes $\mathrm{K}^{+} / \mathrm{H}^{+}$exchange to move the $\mathrm{K}^{+}$ions out of the cells through the $\mathrm{K}^{+}$leak channels.

Therefore, Ca sufficiency provides the high $[\mathrm{K}]_{\mathrm{H}}$ values as seen from the results for $\mathrm{S} 1 \sim \mathrm{S} 5$ (male) before (B) and after (A) the supplementation. Hair samples from breast-cancer patients RC1 RC3 show that the $[\mathrm{K}]_{\mathrm{H}}$ value is greatly increased by removing the cancer with an operation. This suggests that breast cancer increases $[\mathrm{PTH}]$ in serum, and that low $[\mathrm{K}]_{\mathrm{H}}$ can be a marker for the disease.

In comparison of $[\mathrm{Ca}]_{\mathrm{H}}$ and $[\mathrm{K}]_{\mathrm{H}}$, many subjects having the normal $[\mathrm{Ca}]_{\mathrm{H}}$ in Fig. 3 show very low $[\mathrm{K}]_{\mathrm{H}}$ values in Fig. 5. This fact means that $[\mathrm{K}]_{\mathrm{H}}$ is much more sensitive to serum $[\mathrm{PTH}]$ than $[\mathrm{Ca}]_{\mathrm{H}}$; the serum $[\mathrm{PTH}]$ range for channel gating of the $\mathrm{K}$ ion is lower than that of the $\mathrm{Ca}$ ion. It is likely that $[\mathrm{Cl}]_{\mathrm{H}}$ and $[\mathrm{Br}]_{\mathrm{H}}$ reflect $\left[\mathrm{H}^{+}\right]$in serum while $[\mathrm{K}]_{\mathrm{H}}$ reflects $\left[\mathrm{H}^{+}\right]$in cell, but $[\mathrm{K}]_{\mathrm{H}}$ is more sensitive to serum $[\mathrm{PTH}]$ than $[\mathrm{Cl}]_{\mathrm{H}}$ and $[\mathrm{Br}]_{\mathrm{H}}$.

\subsection{Sulphur}

Sulfur intake is mainly through sulfur-containing amino acids, methionine and cysteine. Very high [S] concentrations in hair have been reported as a standard [1]. However, hair $[\mathrm{S}]_{\mathrm{H}}$ was also found to have two separate levels suggesting channel gating, although ion channels for $\mathrm{SO}_{4}{ }^{2-}$ of the sulfur species in serum [15] have not been reported to the knowledge of the authors [16]. For this discussion we will assume that hair sulfur is transported as protein-bound sulfate and ionic sulfate in gated channels not yet discovered.

Figure 5 shows hair root $[\mathrm{S}]_{\mathrm{H}}$ values observed for the same samples as those in Fig. 2; most of the 50 subjects have $[\mathrm{S}]_{\mathrm{H}}=200$. However, it is seen from the samples labelled "S1" to "S5" (male) that the Ca supplementation reduces the upper level at $[S]_{\mathrm{H}}=200$ to the lower normal level of $[S]_{\mathrm{H}}=20$. The subjects labelled N1 (female) and S1-A (male) have the lower $[\mathrm{S}]_{\mathrm{H}}$ level. The lower and upper levels of hair $[\mathrm{S}]_{\mathrm{H}}$ correspond to closing and gating of the assumed channels for $\mathrm{SO}_{4}{ }^{2-}$ of the HM cells. The intermediate $[\mathrm{S}]_{\mathrm{H}}$ values between the two levels can be seen as an average of channel gating.

Similarly to the case of $\mathrm{Ca}$, serum contains sulfur as both anionic $\mathrm{SO}_{4}{ }^{2-}$ and its related forms in protein molecules; $[\mathrm{S}]_{\mathrm{S}}=[\mathrm{S}]_{\mathrm{I}}+[\mathrm{S}]_{\mathrm{P}}$. From Table 1 and Fig. 5, the serum $[\mathrm{S}]_{\mathrm{S}}=40$ is twice the lower level of $[S]_{\mathrm{H}}=20$. This means that $[\mathrm{S}]_{\mathrm{P}}=[\mathrm{S}]_{\mathrm{I}}$. In the case of ion channel closing, only sulfur in serum protein is incorporated into hair, and

$$
[\mathrm{S}]_{\mathrm{HC}}=[\mathrm{S}]_{\mathrm{P}} .
$$

When $\mathrm{S}$ is incorporated into the hair protein by forming a yet unidentified paired species, we have

$$
[\mathrm{S}]_{\mathrm{HO}}=(1 / 2)[\mathrm{S}]_{\mathrm{I}}^{2} .
$$




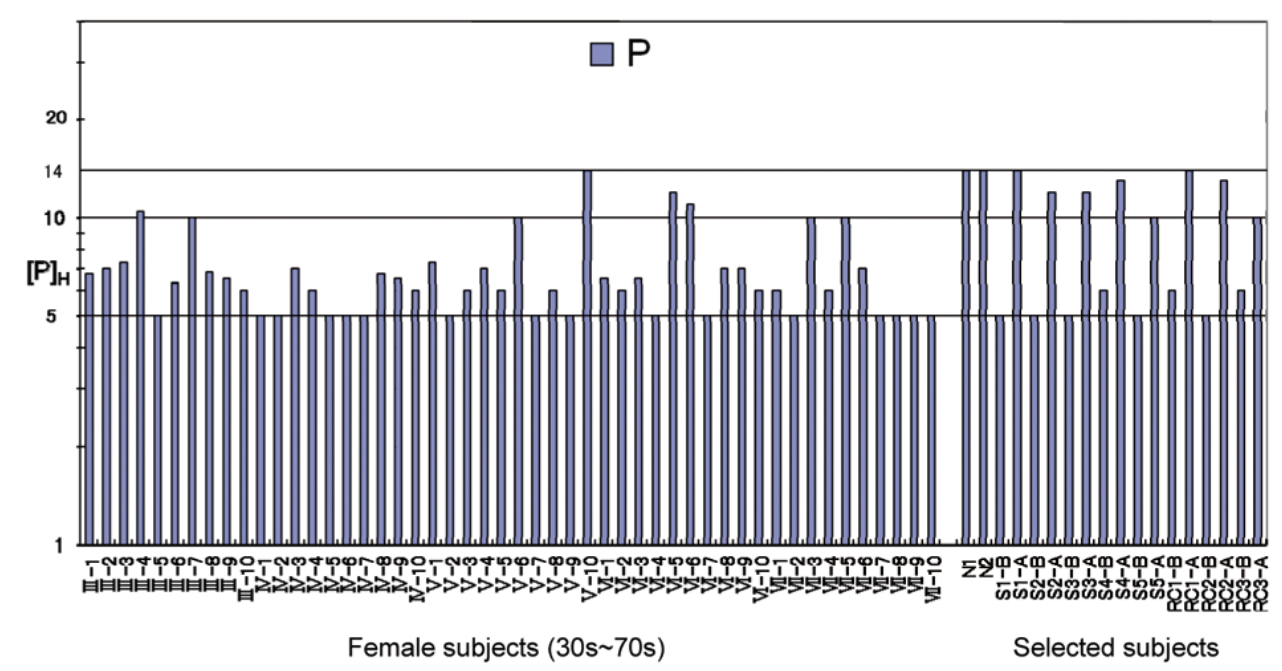

Fig. 6. Hair concentration $[\mathrm{P}]_{\mathrm{H}}$ for the same samples as those in Fig. 2. The upper and lower level are seen at $[\mathrm{P}]_{\mathrm{H}} \geqslant 10$ and $[\mathrm{P}]_{\mathrm{H}}=5$, respectively. The Ca supplementation for $\mathrm{S} 1 \sim \mathrm{S} 5$ shows that the upper level is normal, suggesting active hair making cells with a sufficient energy supply of ATP. All the upper levels without Ca supplementation are due to bone resorption showing $[\mathrm{Cl}]_{\mathrm{H}}=[\mathrm{Br}]_{\mathrm{H}}<10$ in Fig. 4. The lower level is considered to be produced by phosphate-ion channel gating in the cells, and is within the uncertainties of small XFA peaks adjacent to the very high S peak. (Colours are visible in the online version of the article; http://dx.doi.org/10.3233/XST-140439)

Using $[S]_{\mathrm{I}}=20$, we obtain $[\mathrm{S}]_{\mathrm{HO}}=200$ as observed in Fig. 5 .

Using the total serum $[\mathrm{S}]_{\mathrm{S}}=98 \mathrm{mg} / \mathrm{dL}[17]$, the hair lower and upper level are calculated to be $[\mathrm{S}]_{\mathrm{HC}}=$ $4.9 \mathrm{mg} / \mathrm{g}$ and $[\mathrm{S}]_{\mathrm{HO}}=49 \mathrm{mg} / \mathrm{g}$, respectively.

The $\mathrm{SO}_{4}{ }^{2-}$ concentration $[\mathrm{S}]_{\mathrm{I}}$ in serum is controlled mainly with its renal reabsorption by $\mathrm{Na}^{+}$dependent cotransporters of anions in cell membranes of the proximal convoluted tubule (PCT), which is inhibited by PTH receptors expressed in PCT cells $[10,18]$. In serum, therefore, increase of [PTH] causes deficiency of $\mathrm{SO}_{4}{ }^{2-}$ resulting in the anion channel gating of cells, i.e., the upper $[\mathrm{S}]_{\mathrm{H}}$ level is due to PTH secreted by Ca deficiency.

In Fig. 5, for examples, V-6 and V-10 are at the normal high $[\mathrm{K}]_{\mathrm{H}}$ level, but their $[\mathrm{S}]_{\mathrm{H}}$ values are still higher than the standard. This indicates a higher sensitivity of $[\mathrm{S}]_{\mathrm{H}}$ to serum $[\mathrm{PTH}]$. Perhaps due to metabolic differences, the lower level of $[\mathrm{S}]_{\mathrm{H}}=20$ was often observed for male but rare for female subjects.

\subsection{Phosphorus $P$}

PTH secreted with Ca deficiency causes bone resorption, which releases phosphate $\mathrm{HPO}_{4}{ }^{2-}$ from bone into serum. This phosphate increase is considered to exceed the effect by the PTH-inhibition of renal reabsorption $\left(\mathrm{Na}^{+}-\mathrm{HPO}_{4}{ }^{2-}\right.$ cotransport in the proximal tubular cells) $[10,19]$. Therefore, it is expected that $\mathrm{Ca}$ deficiency results in increase of serum phosphate and closes $\mathrm{HPO}_{4}{ }^{2-}$ channels [20] in cells.

Figure 6 shows hair root $[\mathrm{P}]_{\mathrm{H}}$ concentrations observed for the same samples as those in Fig. 2. The upper and lower levels are seen at $[\mathrm{P}]_{\mathrm{H}}=10 \sim 14$ and $[\mathrm{P}]_{\mathrm{H}}=5$, respectively. About a half of the 50 female subjects have intermediate values between the two levels. The effect of the 2-month Ca supplementation can be seen for the male subjects labelled S1 S5 on the right side of Fig. 6; the $[\mathrm{P}]_{\mathrm{H}}$ at the lower level transfers to the upper level by the supplementation. This means that the upper level is the normal. 
Now, we consider the relation of the two $[\mathrm{P}]_{\mathrm{H}}$ levels with the total serum $[\mathrm{P}]_{\mathrm{S}}=4$ in Table 1 . The Gamble gram [15] shows that the $\mathrm{HPO}_{4}{ }^{2-}$ concentration in cells is much higher than that in serum. This indicates that the $\mathrm{HPO}_{4}{ }^{2-}$ ions are pumped into cells by the molecular pumps in their membranes, similarly to the case of $\mathrm{K}$ (See Section 3.5). Therefore, the upper level $[\mathrm{P}]_{\mathrm{H}}=10 \sim 14$ and lower level $[\mathrm{P}]_{\mathrm{H}}=5$ correspond to closing and gating $\mathrm{HPO}_{4}{ }^{2-}$ channels with the pumping, respectively.

The upper level is normal and is reached by pumping with closing channels. Therefore, the observed value $[\mathrm{P}]_{\mathrm{H}}=10 \sim 14$ must be obtained from the Gamble gram [15]; the numbers of $\mathrm{P}$ atoms per protein molecule, $\left[\mathrm{HPO}_{4}{ }^{2-}\right] /\left[\left[\right.\right.$ Protein $\left.^{-}\right](=2 / 16)$ in serum and $\left[\mathrm{HPO}_{4}{ }^{2-}\right] /\left[\left[\right.\right.$ Protein $\left.^{-}\right](=110 / 71)$ in cells (ibid.) correspond to dried serum $[\mathrm{P}]_{\mathrm{I}}\left([\mathrm{P}]_{\mathrm{S}}=[\mathrm{P}]_{\mathrm{I}}+[\mathrm{P}]_{\mathrm{P}}\right)$ and cell $[\mathrm{P}]_{\mathrm{CI}}$ respectively, i.e., $[\mathrm{P}]_{\mathrm{CI}} /[\mathrm{P}]_{\mathrm{I}}=$ $(110 / 71) /(2 / 16)=12.4$ (If $[\mathrm{P}]_{\mathrm{I}}+[\mathrm{P}]_{\mathrm{P}}$ is taken for serum and cell as used in the Gamble gram, the ratio is the same). Serum contains both inorganic phosphorus $[\mathrm{P}]_{\mathrm{S}}=[\mathrm{P}]_{\mathrm{P}}+[\mathrm{P}]_{\mathrm{I}}$ and phospholipids having a negatively charged $\mathrm{PO}_{4}$, paired with positively charged protein molecules adsorbing $\mathrm{HPO}_{4}{ }^{2-}$ to achieve neutrality. We consider phosphorus as occurring in three forms: $[\mathrm{P}]_{\mathrm{I}}$ of biphosphate ions $\mathrm{HPO}_{4}{ }^{2-},[\mathrm{P}]_{\mathrm{P}}$ of protein, and $[\mathrm{P}]_{\text {Pair }}$ of phospholipid-protein pairs ([Protein $] \gg$ [phospholipid]). The $[\mathrm{P}]_{\mathrm{S}}=4$ in dried serum is distributed into these forms with the ratio of 1:1:2 by assuming an equal chemical potential, i.e., $[\mathrm{P}]_{\mathrm{I}}=4 / 4=1$. Then, we have the hair $[\mathrm{P}]_{\mathrm{H}}=[\mathrm{P}]_{\mathrm{P}}+[\mathrm{P}]_{\mathrm{CI}}=1+1 \times 12.4=13.4$ with good agreement with the observed maximum $[\mathrm{P}]_{\mathrm{H}}=14$. (Steady state: $[\mathrm{P}]_{\mathrm{H}}$ is equal to the supply to HM cell)

The lower level $[\mathrm{P}]_{\mathrm{H}}=5$ is produced by the gating channel and the pumping into the HM cell. We assume that $\mathrm{P}$ atoms exist as pairs such as in pyrophosphate (diphosphate) $\mathrm{P}_{2} \mathrm{O}_{7}{ }^{4-}$ in $\mathrm{HM}$ cells and as single phosphate species in hair. Then, using the ion concentration $[\mathrm{P}]_{\mathrm{CI}}$ in the cells, the $[\mathrm{P}]_{\mathrm{H}}$ is given by

$$
[\mathrm{P}]_{\mathrm{H}}=\left\{2[\mathrm{P}]_{\mathrm{CI}}\right\}^{1 / 2},
$$

with the equilibrium consideration similar to the case of Eq. (6) for $\mathrm{Ca}$ (also, see Eq. (12) for $\mathrm{Cl}$ and $\mathrm{Br}$ in Section 3.4). Pyrophosphoric acid is a by-product at synthesis of DNA and is likely to be formed in HM cells with the gene expression for hair growth.

Channel gating occurs so as to keep the homeostasis concentration in the cell even with a deficiency of the concentration in serum. Therefore we can take $[\mathrm{P}]_{\mathrm{CI}}=12.4$ as obtained above. Then, we have $[\mathrm{P}]_{\mathrm{H}}=(2 \times 12.4)^{1 / 2}=5$ by Eq. (16). This value agrees with the lower level $[\mathrm{P}]_{\mathrm{H}}=5$ observed, within the uncertainties of such small XFA peaks.

In observation of $[\mathrm{P}]$ by FXA, absorption of the $\mathrm{PK} \alpha$ peak by the specimen must greatly reduce the number of $2.01 \mathrm{keV}$ photons reaching the detector, and the $\mathrm{P}$ emission can be so weak as to be unusable. Where the signal is sufficient, the calculation of concentration of $P / S$ by Eq. (2) is valid because the absorption for the peak $P$ and background $S$ is produced by the same matrix. In this work, because of the low concentration of $\mathrm{P}$, the absorbance mentioned, and the closeness of the $\mathrm{S}$ peak, the results at the lower level should be considered to be approximations.

\section{Types of Ca deficiency observed in hair}

Ca deficiency has been observed in the four types of hair [Ca] level: "DA" "DO" "DE" "LD" types.

Subjects keeping the normal level $[\mathrm{Ca}]_{\mathrm{H}}=10$ are healthy and referred to as "EE-type" (Ca Ever Enough for closing Ca channels) [6]. We have observed this type in a very few of the female subjects of this study.

As seen in Figs 3 and 4, there are $[\mathrm{Ca}]_{\mathrm{H}}$ values lower than $[\mathrm{Ca}]_{\mathrm{H}}=10$ with $[\mathrm{Cl}]_{\mathrm{H}}=[\mathrm{Br}]_{\mathrm{H}} \gg 10$ due to a deviation toward acidosis. Subjects having $[\mathrm{Ca}]_{\mathrm{H}}<10$ over a long term are called "DA-type" (Ca Deficiency with a deviation toward Acidosis). 
As the opposite of the DA type, there are the values $[\mathrm{Ca}]_{\mathrm{H}}=[\mathrm{Sr}]_{\mathrm{H}}>10$ with $[\mathrm{Cl}]_{\mathrm{H}}=[\mathrm{Br}]_{\mathrm{H}}<10$ due to a deviation toward alkalosis with Ca channel closing, as seen for V-6, VI-6, VII-5, and VII-8 in Figs 3 and 4 . This type is characterized by $[\mathrm{Ca}]_{\mathrm{H}}=[\mathrm{Ca}]_{\mathrm{P}}>10$ due to Ca Deficiency accompanied by a paradoxical Overplus of serum $\left[\mathrm{Ca}^{2+}\right]$ with bone resorption and is referred to as "DO" type.

Transition between the two $[\mathrm{Ca}]_{\mathrm{H}}$ levels occurs quickly (instantaneously in principle) so that they can be seen as two well-separated levels in Fig. 3 (See Fig. 6 of the previous report [6]). The transition is, sometimes, so frequent as to give an intermediate values of $10<[\mathrm{Ca}]_{\mathrm{H}} \leqslant 50$. This case is called "DEtype" (Ca Deficiency for Excitation of Ca channel gating). For examples, the peak heights for "IV-6" and "IV-7" in Fig. 3 are slightly lower than $[\mathrm{Ca}]_{\mathrm{H}}=50$, indicating the period of channel gating is longer than that of channel closing.

The upper level of $[\mathrm{Ca}]_{\mathrm{H}}=50$ in Fig. 3 means that the $\mathrm{Ca}$ accumulation in the $\mathrm{HM}$ cells due to the channel gating continues at least for 5 days, since the X-ray excitation beam width of the XFA was $1.4 \mathrm{~mm}$ (4.7 days' hair growth). For 20 30 \% of subjects over 50, the upper level lasts for a long term. This is referred to as "LD-type" (Long-term Ca Deficiency).

Most of female subjects have $[\mathrm{Ca}]_{\mathrm{HC}}=[\mathrm{Ca}]_{\mathrm{P}}<10$ (DA type). Ca in serum protein is a stockpile that the body can tap in cases of Ca deficiency and is ionized to make up for decrease of $[\mathrm{Ca}]_{I}$ with the deviation to acidosis, i.e., the value of $[\mathrm{Ca}]_{\mathrm{HC}}$ is an indicator for the Ca stock. With $[\mathrm{Ca}]_{\mathrm{HC}}=[\mathrm{Ca}]_{\mathrm{P}} \sim$ 8 , the Ca channel gating starts so as to maintain the $[\mathrm{Ca}]_{\mathrm{H}}$ at the normal standard, as has been mentioned in Section 3.3.5. (This channel gating is essentially different from that of DE type with $[\mathrm{Ca}]_{\mathrm{H}}>10$ ) To recover to the normal $[\mathrm{Ca}]_{\mathrm{H}}=[\mathrm{Sr}]_{\mathrm{H}}=10$, two month supplementation of $\mathrm{Ca} 900 \mathrm{mg} / \mathrm{day}(3 \mathrm{ACa})$ is required; this was observed by moving the measurement point from root to tip of the hair samples $\mathrm{S} 1$ to S5 in Fig. 3. For example, compare S4B and S4A observed before and after (during) the supplementation. $\mathrm{DE}$ and LD types recover only to DA type via DO type and require much longer supplementation. Apparently, DA type with $[\mathrm{Ca}]_{\mathrm{H}} \sim 10$ is near the healthy standard.

\subsection{DA type: Deviation toward acidosis}

The PTH inhibits the $\mathrm{H}^{+} / \mathrm{Na}^{+}$exchangers from excreting $\mathrm{H}^{+}$in renal proximal convoluted tubular cells [10]. Consequently, serum $\left[\mathrm{H}^{+}\right]$increases; this deviation of serum $\mathrm{pH}$ toward acidosis changes the equilibrium between serum protein $[\mathrm{X}]_{\mathrm{P}}$ and liquid $[\mathrm{X}]_{\mathrm{I}}$ with movements of anions and cations in the opposite direction. Comparison of Figs 3 and 4 shows that every sample with a low $[\mathrm{Ca}]_{\mathrm{H}}<10$ has a high $[\mathrm{Cl}]_{\mathrm{H}}=[\mathrm{Br}]_{\mathrm{H}} \gg 10$, i.e., $[\mathrm{Cl}]_{\mathrm{H}}=[\mathrm{Br}]_{\mathrm{H}} \gtrsim 22$ as a result exceeding the $\mathrm{Cl}$ upper level, as seen for III-5, III-10, IV-3, IV-8, IV-9, VI-8, VI-10 with Ca channel closing, and III-3, III-6, III-8, III-9, IV-1, IV-2, IV-4, IV-5, IV-10, V-2, V-8, V-9, VI-2, VI-3, VI-7, VI-9, VII-1, VII-2, VII-4, VII-6, VII-9, VII-10 with store-operated Ca channel gating. These high values of $[\mathrm{Cl}]_{\mathrm{H}}=[\mathrm{Br}]_{\mathrm{H}}$ are considered to be produced by the increase in protein-bound halides $[\mathrm{Cl}]_{\mathrm{P}}$ and $[\mathrm{Br}]_{\mathrm{P}}$ with the closing $\mathrm{Cl}$ ion channels of $\mathrm{HM}$ cells caused by the deviation toward acidosis (hair $[\mathrm{Cl}]_{\mathrm{H}}$ is much more sensitive to the deviation than serum $[\mathrm{Cl}]_{\mathrm{S}}$ ). The effect of the 2-month Ca supplementation seen for the subjects labelled $\mathrm{S} 1 \sim \mathrm{S} 5$ in Fig. 4 shows that the lower level $[\mathrm{Cl}]_{\mathrm{H}}=[\mathrm{Br}]_{\mathrm{H}}=10$ is due to the Ca-enough healthy state and the deviation toward acidosis is caused by serum [PTH] increased by Ca deficiency. This implies that the $\mathrm{pH}$ deviation takes place to ionize Ca atoms on serum protein. As seen in Fig. 4, many of the female subjects between their $30 \mathrm{~s}$ and $70 \mathrm{~s}$ are DA type with $[\mathrm{Cl}]_{\mathrm{HC}}=[\mathrm{Br}]_{\mathrm{HC}} \geqslant 22$ (Ca deficiency), although most of male subjects had the normal level $[\mathrm{Cl}]_{\mathrm{HC}}=[\mathrm{Br}]_{\mathrm{HC}}=10$.

For DA type, the serum [PTH] is so high as to be responsible for the low values of $[\mathrm{K}]_{\mathrm{H}} \lesssim 10$ and the maximum of $[\mathrm{S}]_{\mathrm{H}}=200$ (Fig. 5). PTH inhibits $\mathrm{H}^{+} / \mathrm{Na}^{+}$-exchange and $\mathrm{Na}^{+}$-anion cotransport in 
renal proximal tubular cells, resulting in a high $\left[\mathrm{H}^{+}\right]$and a low $\left[\mathrm{SO}_{4}{ }^{2-}\right]$ in serum, respectively. The $\mathrm{H}^{+}$ causes $\mathrm{K}^{+} / \mathrm{H}^{+}$exchange in cells and the low $[\mathrm{K}]_{\mathrm{H}}$ in hair. The low $\left[\mathrm{SO}_{4}{ }^{2-}\right]$ induces gating sulphate ion channels to give the highest value of $[\mathrm{S}]_{\mathrm{H}}=200$ by Eq. (15).

It should be noted that $\mathrm{Ca}$ channel gating of DA type is store-operated with no deterioration of cell functions by the $\mathrm{Ca}$ channel inflow. For DA type, bone resorption is expected to be minor, and we have the lower level $[\mathrm{P}]_{\mathrm{H}}=5$ in many cases.

\subsection{DO type: Deviation toward alkalosis}

DO type has a value of $[\mathrm{Ca}]_{\mathrm{H}} \geqslant 10$ due to a deviation toward alkalosis with Ca channel closing $\left([\mathrm{Ca}]_{\mathrm{H}}=[\mathrm{Sr}]_{\mathrm{H}}\right)$, as seen for III-4, III-7, V-6, V-10, VI-5, VI-6, VII-3, VII-5, VII-8, N1, and N2, accompanying a low $\mathrm{Cl}$ value of $[\mathrm{Cl}]_{\mathrm{H}}=[\mathrm{Br}]_{\mathrm{H}}<10$. (For III-7, $[\mathrm{Cl}]_{\mathrm{H}}=[\mathrm{Br}]_{\mathrm{H}}=22$ in Fig. 4 is from Cl channel gating due to a low serum $[\mathrm{Cl}])$.

Although its channels are closed in DO type, its Ca deficiency is so serious as to cause bone resorption which increases serum $[\mathrm{P}]$ and can be seen as the upper level of $[\mathrm{P}]_{\mathrm{H}}$ in Fig. 6; all the subjects listed above show the upper level of $[\mathrm{P}]_{\mathrm{H}} \gtrsim 10$, except VII-8 taking a Ca supplement. As has been seen from $\mathrm{S} 1-\mathrm{S} 5$ in Fig. 6, the upper $[\mathrm{P}]_{\mathrm{H}}$ level is the normal achieved by the long-term Ca supplementation. It is questioned why the $\mathrm{Ca}$ deficiency responsible for bone resorption results in the same level. A sufficiency of $\mathrm{Ca}$ with the normal $[\mathrm{Cl}]_{\mathrm{H}}=[\mathrm{Br}]_{\mathrm{H}}=10$ is considered to activate cells that have an energy supply of fully phosphated ATP. In type DO, bone resorption causes an overplus in serum $\left[\mathrm{Ca}^{2+}\right]$ with a deviation toward alkalosis of a low $[\mathrm{Cl}]_{\mathrm{H}}=[\mathrm{Br}]_{\mathrm{H}}<10$.

For DO type, the serum $[\mathrm{PTH}]$ is so low as to result in the high values of $[\mathrm{K}]_{\mathrm{H}}$, and lower values of $\mathrm{S}_{\mathrm{H}}$ for some of the subjects as seen in Fig. 5. This is the opposite of the DA type. The breast-cancer patients $\mathrm{RC} 1$ and $\mathrm{RC} 2$ show that removal of cancer by an operation improves Ca channel gating to closing of a DO type.

It is likely that the serum $\left[\mathrm{Ca}^{2+}\right]$ is kept normal with variations between DA and DO type by serum $\mathrm{PH}$ deviation with the equality of $[\mathrm{Cl}]_{\mathrm{H}}=[\mathrm{Br}]_{\mathrm{H}}$.

\subsection{DE-type and LD-type: Deviation toward alkalosis}

Deviations to alkalosis with a very low $[\mathrm{Cl}]_{\mathrm{H}}\left(=[\mathrm{Cl}]_{\mathrm{P}}\right)$ can be seen for some subjects in Fig. 4. They are the LD-type with $[\mathrm{Ca}]_{\mathrm{H}}=50$ labelled V-3, V-4, VI-4, VII-7 and DE-type labelled IV-6, IV7 ; the low values of $[\mathrm{Cl}]_{\mathrm{H}} \ll 10$ are associated with the $\mathrm{Ca}$ channel gating revealed by the inequality $[\mathrm{Ca}]_{\mathrm{H}}<[\mathrm{Sr}]_{\mathrm{H}}$. The $\mathrm{Ca}$ inflow through gating channels deteriorates the cell functions, as has been mentioned in Section 3.4. The alkalosis is due to the deterioration of erythrocyte function, and the erythrocytes' role in the chloride shift keeps the serum $\mathrm{pH}$ normal.

Simultaneously, the $\mathrm{Ca}$ inflow takes place in hepatocytes. Their function to excrete excess metals in serum into bile deteriorates and results in the values $[\mathrm{Cu}]_{\mathrm{H}}>10$ as seen from the samples labelled IV-6, IV-7, V-3, V-4, VI-4, and VII-7 in Fig. 2 (Compare with Fig. 3). The deterioration also causes an increase in $[\mathrm{Ti}]_{\mathrm{H}}$.

To recover from such cell deterioration, it takes a long time. Abnormal values of $[\mathrm{Cl}]_{\mathrm{H}},[\mathrm{Cu}]_{\mathrm{H}}$, and $[\mathrm{Ti}]_{\mathrm{H}}$ are seen due to past damage $[21]$ even though the normal $[\mathrm{Ca}]_{\mathrm{H}}=[\mathrm{Sr}]_{\mathrm{H}}$ is present, as seen for III-1 (Ti), V-7 (Ti) and V-10 (Cu). Although such cell deterioration should not be expected for store-operated Ca channel gating with $[\mathrm{Ca}]_{\mathrm{H}}<10$, the past must be taken into account. A subject with a history of type LD deficiency will show the inequality $[\mathrm{Cl}]_{\mathrm{H}}<[\mathrm{Br}]_{\mathrm{H}}$ or $[\mathrm{Cl}]_{\mathrm{H}}=[\mathrm{Br}]_{\mathrm{H}}<10$ at present, as seen from III-1, V-1, V-7, VI-1 having a high $[\mathrm{Ti}]_{\mathrm{H}}$. 
Table 2

Classification of hair concentrations due to Ca deficiency

\begin{tabular}{|c|c|c|c|}
\hline$[\mathrm{Ca}]_{\mathrm{H}}>10$ & $\begin{array}{l}\text { PTH-operated Ca channel gating: }[\mathrm{Ca}]_{\mathrm{H}}<[\mathrm{Sr}]_{\mathrm{H}} \\
\quad \text { Gating frequency: high } \\
\mathrm{Ca}^{2+} \text { inflow into cell } \\
\quad \text { Alkalosis } \\
\text { Liver function: low } \\
\text { Renal H }{ }^{+} \text {excretion: low } \\
\text { Renal reabsorption: low } \\
\text { Bone resorption: high }\end{array}$ & $\begin{array}{l}{[\mathrm{Ca}]_{\mathrm{H}}=50} \\
10 \lesssim[\mathrm{Ca}]_{\mathrm{H}}<50 \\
{[\mathrm{Cl}]_{\mathrm{H}} \lesssim[\mathrm{Br}]_{\mathrm{H}}=10 \text { Independent }} \\
{[\mathrm{Cl}]_{\mathrm{H}}<10<[\mathrm{Br}]_{\mathrm{H}} \text { Compensatory }} \\
{[\mathrm{Cu}]_{\mathrm{H}}>10 \text { and/or }[\mathrm{Ti}]_{\mathrm{H}}: \text { high }} \\
{[\mathrm{K}]_{\mathrm{H}} \lesssim 10} \\
{[\mathrm{~S}]_{\mathrm{H}}=200} \\
{[\mathrm{P}]_{\mathrm{H}} \sim 10}\end{array}$ & DE type, LD type \\
\hline$[\mathrm{Ca}]_{\mathrm{H}} \gtrsim 10$ & $\begin{array}{l}\text { Ca channel closing: }[\mathrm{Ca}]_{\mathrm{H}}=[\mathrm{Sr}]_{\mathrm{H}} \text { Bone Resorption } \\
{[\mathrm{Ca}]_{\mathrm{I}} \text { overplus }[\mathrm{Ca}]_{\mathrm{P}} \gg[\mathrm{Ca}]_{\mathrm{I}}} \\
\text { Deviated toward alkalosis } \\
\text { No } \mathrm{Ca}^{2+} \text { inflow into cell } \\
\text { Low }[\mathrm{PTH}] \text { at present } \\
\text { Bone resorption: high (past) }\end{array}$ & $\begin{array}{l}{[\mathrm{Ca}]_{\mathrm{P}}=[\mathrm{Ca}]_{\mathrm{H}} \gtrsim 10} \\
{[\mathrm{Cl}]_{\mathrm{H}}=[\mathrm{Br}]_{\mathrm{H}}<10} \\
{[\mathrm{Cu}]_{\mathrm{H}} \lesssim 10 \text { and }[\mathrm{Ti}]_{\mathrm{H}}: \text { low }} \\
{[\mathrm{K}]_{\mathrm{H}} \approx 300 \quad[\mathrm{~S}]_{\mathrm{H}}<200} \\
{[\mathrm{P}]_{\mathrm{H}} \gtrsim 10}\end{array}$ & DO type \\
\hline$[\mathrm{Ca}]_{\mathrm{H}}=10$ & $\begin{array}{l}\text { Ca channel closing: }[\mathrm{Ca}]_{\mathrm{H}}=[\mathrm{Sr}]_{\mathrm{H}}=10 \\
{[\mathrm{Cl}]_{\mathrm{H}}=[\mathrm{Br}]_{\mathrm{H}}=10 \quad[\mathrm{Cu}]_{\mathrm{H}} \lesssim 10 \text { and }[\mathrm{Ti}]_{\mathrm{H}} \text { : low }} \\
{[\mathrm{K}]_{\mathrm{H}} \sim 300 \quad[\mathrm{~S}]_{\mathrm{H}}=20 \quad[\mathrm{P}]_{\mathrm{H}} \gtrsim 10 \text { (activated with }}\end{array}$ & & EE type \\
\hline$[\mathrm{Ca}]_{\mathrm{H}} \leqslant 10$ & $\begin{array}{l}\text { Ca channel closing: }[\mathrm{Ca}]_{\mathrm{H}}=[\mathrm{Sr}]_{\mathrm{H}} \\
\text { Deviation to acidosis by PTH } \\
\mathrm{No} \mathrm{Ca}^{2+} \text { inflow into cell } \\
\text { Renal } \mathrm{H}^{+} \text {excretion: low } \\
\text { Renal reabsorption: low } \\
\text { Bone resorption: low }\end{array}$ & $\begin{array}{l}{[\mathrm{Ca}]_{\mathrm{P}}=[\mathrm{Ca}]_{\mathrm{H}} \lesssim 10} \\
{[\mathrm{Cl}]_{\mathrm{H}}=[\mathrm{Br}]_{\mathrm{H}}>10} \\
{[\mathrm{Cu}]_{\mathrm{H}} \lesssim 10 \text { and }[\mathrm{Ti}]_{\mathrm{H}}: \text { low }} \\
{[\mathrm{K}]_{\mathrm{H}} \lesssim 10} \\
{[\mathrm{~S}]_{\mathrm{H}}=200} \\
{[\mathrm{P}]_{\mathrm{H}} \sim 5}\end{array}$ & DA type \\
\hline$[\mathrm{Ca}]_{\mathrm{H}}<10$ & $\begin{array}{l}\text { Store-operated Ca channel gating: }[\mathrm{Ca}]_{\mathrm{H}}<[\mathrm{Sr}]_{\mathrm{H}} \\
\text { Toward maintaining the normal } \\
\text { Deviation to acidosis by PTH } \\
\text { No exceeding the Ca normal } \\
\text { Renal } \mathrm{H}^{+} \text {excretion: low } \\
\text { Renal reabsorption: low } \\
\text { Bone resorption: low }\end{array}$ & $\begin{array}{l}{[\mathrm{Ca}]_{\mathrm{P}}=[\mathrm{Ca}]_{\mathrm{H}} \lesssim 10} \\
{[\mathrm{Cl}]_{\mathrm{H}}=[\mathrm{Br}]_{\mathrm{H}}>10} \\
{[\mathrm{Cu}]_{\mathrm{H}} \lesssim 10 \text { and }[\mathrm{Ti}]_{\mathrm{H}}: \text { low }} \\
{[\mathrm{K}]_{\mathrm{H}} \lesssim 10} \\
{[\mathrm{~S}]_{\mathrm{H}}=200} \\
{[\mathrm{P}]_{\mathrm{H}} \sim 5}\end{array}$ & DA type \\
\hline
\end{tabular}

$[\mathrm{Cu}]_{\mathrm{H}}$ values normalized by Eq. (3).

As mentioned before, DA type recovers with the two month supplementation. Such a DA type with a low $[\mathrm{Ca}]_{\mathrm{H}}=[\mathrm{Ca}]_{\mathrm{P}}<10$ continues even when the serum $\left[\mathrm{Ca}^{2+}\right]$ increases to the DO-type level of $\mathrm{Ca}$ overplus by bone resorption, i.e., DA type having $[\mathrm{Ca}]_{\mathrm{H}}<10$ and $[\mathrm{Cl}]_{\mathrm{H}}\left(=[\mathrm{Br}]_{\mathrm{H}}\right)<10$ can exist in the serum state of DO type, as seen for V-7, VI-1, VI-5 and VII-4 in Figs 3 and 4. This is referred to as "DA-DO" type.

The relation between the 4 types of Ca deficiency and elemental concentrations $[\mathrm{X}]_{\mathrm{H}}$ in hair are summarized in Table 2.

\section{Conclusion}

Usually, the observation of homeostasis is beyond our measurement. By using the log ratio of peak to background, $\log [\mathrm{X}]=\log (P / S)$, XF analysis can be used to monitor both short and long-term changes in element flow into hair, without the lengthy measurement process needed for conventional full quantitation. 
The dried serum samples from 5 male and 5 female subjects treated with Ca supplementation showed similar FX peak heights for $\mathrm{Ca}$, and for the other elements $\mathrm{Sr}, \mathrm{P}, \mathrm{S}, \mathrm{K}, \mathrm{Cl}$, and $\mathrm{Br}$ (with one exception) under renal control, see Table 1, and give the standard concentrations. The content of an element in hair growing in a steady state provides a sound indication of the influx of the element from serum. Using this principle, both the upper and lower levels for $[\mathrm{Ca}],[\mathrm{Sr}],[\mathrm{Cl}],[\mathrm{Br}],[\mathrm{K}],[\mathrm{S}]$ and $[\mathrm{P}]$ in hair were calculated from their standard concentrations (Table 1) observed for dried serum. Ca deficiency can be clearly classified into the DA, DO, DE, and LD types, as shown in Table 2. Unhealthy states and diseases can be detected as a deviation from the normal pattern over time, undetectable by the serum analysis, except perhaps with tedious and intrusive repeated analyses. The types of Ca deficiency have been explained by channel gating and closing for each element. $\mathrm{Ca}$ is the central player in the regulation of the serum and cell concentrations of the many other elements, and the store-operated Ca channels act to keep $[\mathrm{Ca}]_{\mathrm{H}}$ at the normal value in a range of $[\mathrm{Ca}]_{\mathrm{H}} \leqslant 10$.

The elemental concentrations incorporated in a steady-state hair growth are independent of the growth rate [6], and the Ca deficiency observed in hair is also considered to occur in epithelial cells lining the body cavities, where carcinoma originates. The authors' parallel study [21] is associated with breast cancer, and the main subjects are female. The $\mathrm{Ca}^{2+}$ inflow into cells is considered to trigger various diseases, and the hair analysis provides a new diagnosis on cell ion channel gating.

\section{Acknowledgments}

This work has been performed under the approval of the Photon Factory (Proposal No. 2005R15, 2006G408, 2009Y011, 2009Y022, 2010Y023) in collaboration with Health Analysis Laboratory, Ltd. The authors would like to express their sincere thanks to Professor A. Iida, Photon Factory, for his great help with the experiment at BL-4A. His sophisticated instrumentation enabled us to find the relation in elemental concentration between serum and hair. They are also indebted to Emeritus Professor T. Fujita (Kobe University), Emeritus Professor Y. Kudo (Tokyo University of Pharmacy and Life Sciences) and Professor K. Shinohara (Waseda University) for giving us much useful advice. The authors gratefully acknowledge great help throughout this work by Ms. S. Ooike in Centre for Advanced Science and Technology, Hyogo. Finally, the authors would like to acknowledge the review of the manuscript by Jeremy Salter (an American writer and retired pharmaceutical chemist). Without their help, this publication might be impossible, and the authors are deeply grateful for the efforts of these scholars.

\section{References}

[1] I. Orlic, J. Makjanic and V. Valkovic, Comparison of particle and photon excited X-ray characteristic spectra applied to elemental analysis of hair samples, Nucl Instr Meth Phys Res B3 (1984), 250-252.

[2] L. Hong-Kou and K.R. Akselsson, Rutherford backscattering - A tool for quantification of the results of PIXE analysis of single hair strands, Nuc Instr Meth Phys Res B12 (1985), 265-268.

[3] A. Iida and T. Noma, Synchrotron X-ray microprobe and its application to human hair analysis, Nucl Instr Meth Phys Res B82 (1993), 129-138.

[4] Y. Kolmogorov, V. Kovaleva and A. Gonchar, Analysis of trace elements in scalp hair of healthy people, hyperplasia and breast cancer patients with XRF method, Nucl Instr Meth Phys Res A448 (2000), 457-460.

[5] A.M. Aksirov, V.S. Gerasimov, V.I. Kondratyev, V.N. Korneev, G.N. Kulipanov, N.F. Lanina, V.P. Letyagin, N.A. Mezentsev, P.M. Sergienko, B.P. Tolochko, V.A. Trounova and A.A. Vazina, The origin of specific changes of small-angle X-ray diffraction pattern of hair and their correlation with the elemental content, Nucl Instr Meth Phys Res A470 (2001), 380-387. 
[6] J. Chikawa, K. Yamada, T. Akimoto, H. Sakurai, H. Yasui, H. Yamamoto, S. Okabe and M. Ebara, The universal concentrations and cancer signs of trace elements in hair observed by x-ray fluorescence analysis, $J X$-Ray Science and Technology 15 (2007), 109-129.

[7] R. Cornelis, X. Fuentes-Arderiu, I. Bruunshuus and D. Templeton, Properties and units in the clinical laboratory sciences: Part IX. Properties and units in trace elements, Pure and Appl Chem 69 (1997), 2593-2606.

[8] T. Fujita and G.M.A. Palumieri, Calcium paradox disease: Calcium deficiency prompting secondary hyperparathyroidism and cellular calcium overload [review article], J Bone Miner Metab 18 (2000), 109-125.

[9] E.M. Brown and H. Jüppner, Parathyroid Hormone: Syntheses, Secretion, and Action, in: Primer on the Metabolic Bone Diseases and Disorders of Mineral Metabolism, Chapter 15, (6th edition), M.J. Favus, ed., Washington, DC, American Society for Bone and Mineral Research, 2006, pp. 90-99.

[10] F.R. Bringhurst, Physiologic Actions of PTH and PTHrP II. Renal Actions, in: The Parathyroids, Basic and Clinical Concepts, Chapter 14, (2nd edition), J.P. Bilezikian, R. Marcus and M.A. Levine, eds., San Diego, Academic Press, 2001, pp. 227-243.

[11] T. Fujita, Degenerative joint disease: An example of calcium paradox [review article], J Bone Miner Metab 16 (1998), 195-205.

[12] T. Fujita, Calcium bioavailability from heated oyster shell-seaweed calcium (active absorbable algal calcium) as assessed by urinary calcium excretion, J Bone Miner, Metab 14 (1996), 31-34.

[13] P.C. D'Hasese, G.F. Van Landeghem, L.V. Lamberts, V.A. Bekaert, I. Schrooten and M.E. DeBroe, Measurement of strontium in serum, urine, bone, and soft tissues by Zeeman atomic absorption spectrometry, Clinical Chemistry $\mathbf{4 3}$ (1997), 121-128.

[14] F. Powers, The Role of chloride in acid-base balance, J Intravenous Nursing 22 (1999), 286-291.

[15] J.L. Gamble, Chemical Anatomy, Physiology and Pathology of Extracellular Fluid: a Lecture Syllabus, Cambridge Mass, Harvard University Press, 1949.

[16] E. Ohana, D. Yang, N. Shcheynikov and S. Muallem, Diverse transport modes by the solute carrier 26 family of anion transporters, J Physiol 587 (2009), 2179-2185.

[17] S. Natelson and B. Sheid, X-ray spectroscopy in the Clinical Laboratory III. Sulfur distribution in the electrophoretic protein fractions of human serum; Abnormalities observed in certain disease states, Clinical Chemistry 6 (1960), 314326.

[18] D. Markovich, Physiological roles and regulation of mammalian sulfate transporters, Physiol Rev 81 (2001), 1499-1533.

[19] H. Murer, N. Hernando, I. Forster and J. Biber, Proximal tubular phosphate reabsorption: Molecular mechanisms, Physiol Rev 80 (2000), 1372-1409.

[20] D.R. Laver, G.K. Lenz and A.F. Dulhunty, Phosphate ion channels in sarcoplasmic reticulum of rabit skeletal muscle, $J$ Physiol 535 (2001), 715-728.

[21] J. Chikawa, Y. Mouri, H. Shima, K. Yamada, H. Yamamoto and S. Yamamoto, A correlation of breast cancer and calcium levels in hair analyzed by X-ray fluorescence, to be published in J X-ray Science and Technology. 